\title{
Types of Tellurium Mineralization of Gold Deposits of the Aldan Shield (Southern Yakutia, Russia)
}

\author{
Larisa A. Kondratieva *, Galina S. Anisimova (D) and Veronika N. Kardashevskaia
}

Citation: Kondratieva, L.A.; Anisimova, G.S.; Kardashevskaia, V.N. Types of Tellurium Mineralization of Gold Deposits of the Aldan Shield (Southern Yakutia, Russia). Minerals 2021, 11, 698. https://doi.org/ $10.3390 / \min 11070698$

Academic Editors: Galina Palyanova and Liqiang Yang

Received: 30 April 2021

Accepted: 25 June 2021

Published: 29 June 2021

Publisher's Note: MDPI stays neutral with regard to jurisdictional claims in published maps and institutional affiliations.

Copyright: (c) 2021 by the authors. Licensee MDPI, Basel, Switzerland. This article is an open access article distributed under the terms and conditions of the Creative Commons Attribution (CC BY) license (https:// creativecommons.org/licenses/by/ $4.0 /)$.
Diamond and Precious Metal Geology Institute, SB RAS, 677000 Yakutsk, Russia; gsanisimova1952@mail.ru (G.S.A.); kardashevskaya92@mail.ru (V.N.K.)

* Correspondence: lkon12@yandex.ru; Tel.: +7-4112-33-58-72

\begin{abstract}
The published and original data on the tellurium mineralization of gold ore deposits of the Aldan Shield are systematized and generalized. The gold content is related to hydrothermalmetasomatic processes caused by Mesozoic igneous activity of the region. The formation of tellurides occurred at the very late stages of the generation of gold mineralization of all existing types of metasomatic formations. 29 tellurium minerals, including 16 tellurides, 5 sulfotellurides and 8 tellurates have been identified. Tellurium minerals of two systems predominate: Au-Bi-Te and Au-Ag-Te. Gold is not only in an invisible state in sulfides and in the form of native gold of different fineness, but also is part of a variety of compounds: montbrayite, calaverite, sylvanite, krennerite and petzite. In the gold deposits of the Aldan Shield, three mineral types are distinguished: Au-Ag-Te, Au-Bi-Te, and also a mixed one, which combines the mineralization of both systems. The decrease in the fineness of native gold is consistent with the sequence and temperatures of the formation of Te minerals and associated mineral paragenesis from the epithermal-mesothermal Au-Bi-Te to epithermal Au-Ag-Te. The conducted studies allowed us to determine a wide variety of mineral species and significantly expand the area of distribution of Au-Te mineralization that indicates its large-scale regional occurrence in the Aldan Shield.
\end{abstract}

Keywords: tellurides; gold; $\mathrm{Au}-\mathrm{Bi}-\mathrm{Te} ; \mathrm{Au}-\mathrm{Ag}-\mathrm{Te}$ and mixed $\mathrm{Au}-\mathrm{Ag}$-Bi-Te mineral types; igneous activity; alkaline magmatism; metasomatites; Aldan Shield

\section{Introduction}

One of the main sources of gold in Russia for many decades has been gold mineralization of the Aldan-Stanovoy Shield-the largest outcrop of the Early Precambrian basement of the Siberian platform. The geological structure of the area includes two structural stages: the lower, crystalline basement, composed of metamorphosed Early Archean gneisses, schists, and granites, and the upper, platform cover formed by the Vendian-Lower Cambrian carbonate and Jurassic terrigenous rocks. Two large gold-bearing provinces, Aldan and Stanovaya, are identified on the territory of the Aldan-Stanovoy Shield, located respectively in the geoblocks (shields) of the same name.

The main gold reserves of the Aldan Shield (AS) are concentrated on the territory of the Central Aldan ore District (CAD). The gold content is associated with hydrothermalmetasomatic processes caused by large-scale Mesozoic igneous activity of the region, involving the intrusion of massifs of subalkaline and alkaline high-potassium igneous rocks of the Jurassic-Cretaceous age [1-12]. Ore-bearing hydrothermal-metasomatic formations are represented by sericite-microcline metasomatites, beresites, gumbaites, jasperoids, and argillizites.

Tellurium mineralization in the area of the Aldan Shield was first recorded in the 1970s to 1980s. Epithermal gold-telluride mineralization was described by S. V. Yablokova (1975) and A. A. Kim $(1982,1988,1990,2000)$ in the Kuranakhsky ore cluster of the CAD (Bokovoye and Delbe deposits). In addition to the well-known tellurium and selenium minerals, new mineral types of tellurates have been established: kuranakhite [13], yafsoanite, kuksite, 
cheremnykhite and V, Si-dugganite [14-17]. Recently, new information has appeared on tellurium mineralization in the deposits and ore occurrences of the CAD in the ores of Lebedinsky [18,19], Elkonsky [20-22], Dzhekondinsky [23,24], Yukhtinsky [25,26], and the Nimgerkansky [27] ore fields, as well as a number of other gold ore objects outside the CAD-Verkhne-Tokkinsky [28,29], Verkhneamginsky [30-34], Tyrkandinsky, Guvilgrinsky, Altan-Chaidakhsky, and Verkhnealgominsky [35-38] (Figure 1).

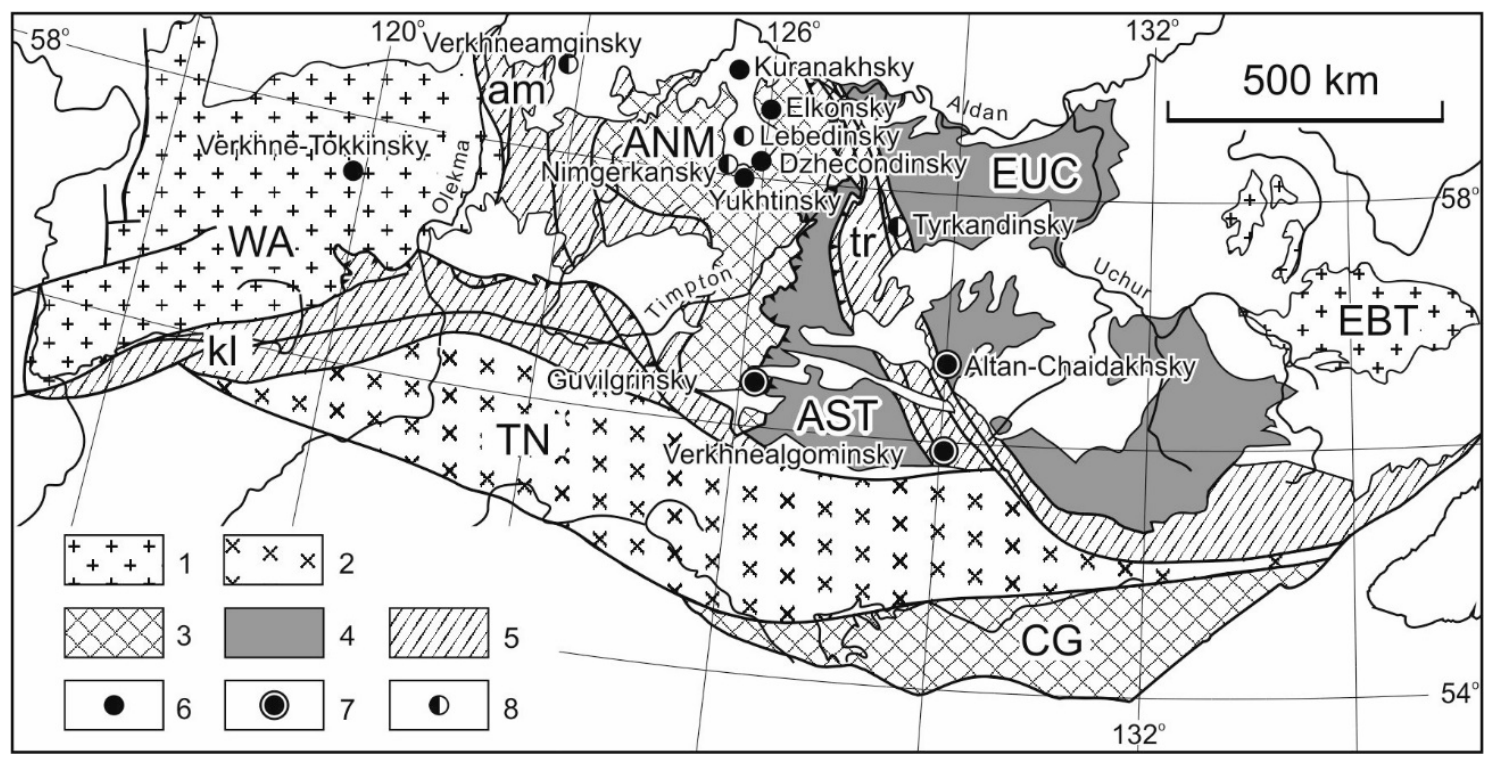

Figure 1. The position of deposits and ore occurrences with telluride mineralization in the structures of the Aldan geoblock of the Aldan-Stanovoy shield. Based on [39]: 1-4-terrains: granite-greenstone (WA-West-Aldan, EBT-Batomgsky, 2-tonalite-trondhjemite gneissic (TN-Tyndinsky), 3-granulite-gneissic (ANM-Nimnyrsky, CG-Chogarsky), 4-granulite-paragneissic (AST-Sutamsky, EUC-Uchursky); 5-zones of tectonic melange (am-Amginskaya, kl-Kalarskaya, tr-Tyrkandinskaya); 6-8—ore districts with Te mineralization: 6—Au-Ag-Te, 7-Au-Bi-Te, 8—mixed.

The significance of the research of tellurides is proved by their important role as indicator minerals of the physical and chemical conditions of the formation of gold mineralization, as well as accessory minerals, containing a significant proportion of the gold reserves.

The purpose of the research: to systematize and summarize the scattered information on Te mineralization of the region, to clarify their typomorphic properties and conditions of ore formation, to typify and determine the patterns of their spatial position in the structures of the Aldan Shield.

\section{Materials and Methods}

Typification of tellurium mineralization of gold deposits of the Aldan shield is carried out on the basis of systematization and generalization of scattered known and original data. About three hundred and fifty samples were collected from mine working of the Verkhneamginsky, Nimgerkansky, Tyrkandinsky, Guvilgrinsky, Altan-Chaidakhsky, and Verkhnealgominsky ore fields. The polished sections made from the samples were optically examined using a Jenavert ore microscope in reflected light, with special attention being directed toward identifying sulfides, sulfosalts, tellurides and native elements. These minerals were analyzed on a Camebax-micro X-ray spectral microanalyzer and a JEOL JSM-6480LV scanning electron microscope with an OXFORD energy spectrometer, where the Back Scattered Electron images were taken at the Diamond and Precious Metal Geology Institute, Siberian Branch, Russian Academy of Sciences (Yakutsk, Russia) (analysts N.V. Khristoforova, S. K. Popova, S. A. Karpova). The quantitative analysis was carried out using Software INCA Energy (Version 4.17, Oxford Instruments, Abingdon, Oxfordshire, UK) with XPP matrix correction scheme developed by Pouchou and Pichoir. Operating conditions included $20 \mathrm{kV}$ voltage, a beam current of $1.08 \mathrm{nA}$ and a beam diameter of $1 \mu \mathrm{m}$, 
measurement time 10 s. Analitical lines: $\mathrm{Bi}-\mathrm{M} \alpha$; Te, Pb, Ag, Sb, S-L $\alpha$; Cu, Fe, Zn, S-K $\alpha$. Standards: gold $750 \%-\mathrm{Au}, \mathrm{Ag}, \mathrm{Bi}_{2} \mathrm{~S}_{3}-\mathrm{Bi}$ (bismuthinite), $\mathrm{HgTe}$ (coloradoite)-Hg, Te, $\mathrm{CuSbS}_{2}$ (chalcostibite)-Cu, Sb, S, Tl (Br,I)-Tl, ZnS (sphalerite)-Zn, CuFeS 2 (chalcopyrite)-Fe, PbS (galena)-Pb, FeAsS (arsenopyrite)-As. Element detection limits ( $\mathrm{wt} \%$ ) X-ray spectral microprobe analysis: Au 0.117, Ag 0.061, $\mathrm{Hg} \mathrm{0.083,} \mathrm{Cu} \mathrm{0.031,} \mathrm{Fe} \mathrm{0.019,} \mathrm{Pb} \mathrm{0.066,} \mathrm{Bi} \mathrm{0.095.}$ Limits of element detection ( $\mathrm{w} t \%)$ scanning electron microscope equipped with energy spectrometer: Au 1.84, Ag 0.96, $\mathrm{Hg}$ 1.6, Cu 1.22, Fe 1.04, Pb 1.78, Bi 2.7.

Microthermometric studies of fluid inclusions were carried out at the Department of Mineralogy of St. Petersburg State University in a thermal chamber mounted on a POLAM P-211 microscope, and also at the "Geomodel" Resource Center Saint Petersburg State University on Olympus BX53F optical microscope complete with microthermometric system THMSG-600-ec with LNP95 liquid nitrogen sample cooling system at temperature range from -196 to $+600{ }^{\circ} \mathrm{C}$. The accuracy of temperature measurements is $\pm 0.1^{\circ} \mathrm{C}$ in the temperature range from -20 to $+20^{\circ} \mathrm{C}$. The composition of the liquid and vapour phases of fluid inclusions in quartz was analyzed there on the Horiba LabRam HR800 Raman spectrometer at the «Geomodel» Resource Center SPSU (analyst V.N. Bocharov), an Ar laser with a wavelength of $514.5 \mathrm{~nm}$ and $488 \mathrm{~nm}$, an exposure time of $3 \mathrm{~s}$, the number of repetitions - 5, the laser power-50 MW, and the magnification of the microscope- $50 \times$.

\section{Results}

\subsection{Tellurium Minerals}

The tellurium mineralization of AS is characterized by a wide diversity of mineral species. Currently, 29 tellurium minerals are found in the ores: 16 tellurides, 5 sulfotellurides, and 8 tellurates, of which 2 are unidentified (Table 1). They usually form micro-and nano-inclusions with a size of 1-20 $\mu \mathrm{m}$, with the exception of the ores of the Bodorono and Khatyrkhay deposits, where the sizes of tellurobismuthite and/or tetradymite reach $3 \mathrm{~mm}$. The shape of the grains is round-oval, elongated, needle-like, or irregular angular. Tellurium minerals occur both as monoinclusions and in ensembles of two or three tellurides.

Table 1. Tellurium minerals of the Aldan Shield.

\begin{tabular}{|c|c|c|}
\hline Tellurides & Sulfotellurides & Tellurates \\
\hline $\begin{array}{c}\text { calaverite }\left(\mathrm{AuTe}_{2}\right) \\
\text { montbrayite } \mathrm{Au}_{2} \mathrm{Te}_{3} \\
\text { krennerite }(\mathrm{AuAgTe}) \\
\text { sylvanite }(\mathrm{AuAg})_{2} \mathrm{Te}_{4} \\
\text { petzite }\left(\mathrm{Ag}_{3} \mathrm{AuTe}_{2}\right) \\
\text { stutzite }\left(\mathrm{Ag}_{4.7} \mathrm{Te}\right) \\
\text { hessite }\left(\mathrm{Ag}_{2} \mathrm{Te}\right) \\
\text { volynskite }\left(\mathrm{AgBiTe}_{2}\right) \\
\text { tellurobismuthite }\left(\mathrm{Bi}_{2} \mathrm{Te}_{3}\right) \\
\text { hedleyite }\left(\mathrm{Bi}_{7} \mathrm{Te}_{3}\right) \\
\text { tsumoite }(\mathrm{BiTe}) \\
\text { rucklidgeite }\left(\mathrm{PbBi}_{2} \mathrm{Te}_{4}\right) \\
\text { merenskyite }\left((\mathrm{Pd}, \mathrm{Pt})(\mathrm{Bi}, \mathrm{Te})_{2}\right) \\
\text { melonite }(\mathrm{NiTe} 2) \\
\text { altaite }(\mathrm{PbTe}) \\
\text { coloradoite }(\mathrm{HgTe})\end{array}$ & $\begin{array}{c}\text { Te-canfieldite }\left(\mathrm{Ag}_{8} \mathrm{Sn}(\mathrm{S}, \mathrm{Te})_{6}\right) \\
\text { cervelleite }\left(\mathrm{Ag}_{4} \mathrm{TeS}\right) \\
\text { tetradymite } \mathrm{Bi}_{2} \mathrm{Te}_{2} \mathrm{~S} \\
\text { sulphotsumoite }\left(\mathrm{Bi}_{3} \mathrm{Te}_{2} \mathrm{~S}\right) \\
\text { goldfieldite } \\
\left(\mathrm{Cu}_{12}(\mathrm{Te}, \mathrm{Sb}, \mathrm{As})_{4} \mathrm{~S}_{13}\right)\end{array}$ & $\begin{array}{c}\text { smirnite }\left(\mathrm{Bi}_{2} \mathrm{TeO}_{5}\right) \\
\text { kuranakhite }\left(\mathrm{PbMnTeO}_{6}\right) \\
\text { yafsoanite }\left((\mathrm{Zn}, \mathrm{Ca}, \mathrm{Pb})_{3} \mathrm{TeO}_{6}\right) \\
\text { kuksite }\left(\mathrm{Pb}_{3} \mathrm{Zn}_{3} \mathrm{TeO}_{6}\left(\mathrm{PO}_{4}\right)_{2}\right) \\
\text { cheremnykhite } \\
\left(\mathrm{Pb}_{3} \mathrm{Zn}_{3} \mathrm{TeO}_{6}\left(\mathrm{VO}_{4}\right)_{2}\right) \\
\text { V,Si-dugganite } \\
\left(\mathrm{Pb}_{3} \mathrm{Zn}_{3} \mathrm{Te}(\mathrm{As}, \mathrm{V}, \mathrm{Si})_{2} \mathrm{O}_{4}(\mathrm{OH})\right) \\
\text { Unidentified Tl tellurates } \\
\text { Unidentified Tl } \\
\text { telluroantimonates }\end{array}$ \\
\hline
\end{tabular}

Tellurium minerals of two systems predominate: Au-Bi-Te and Au-Ag-Te. The tellurides of the Au-Ag-Te system are characterized by the greatest diversity. Seven minerals have been identified. These minerals often form inclusions in pyrite, and are also found in calcite, quartz, bornite, and tennantite (Figure 2). Among the minerals of the Au-Bi-Te system, the most common are the tellurides of the tetradymite group (tellurobismuthite, tetradymite, tsumoite, sulfotsumoite, and hedleyite). Tellurides are commonly found in pyrite, galena, galenobismutite, chalcopyrite, pyrrhotite, and quartz (Figure 3). 

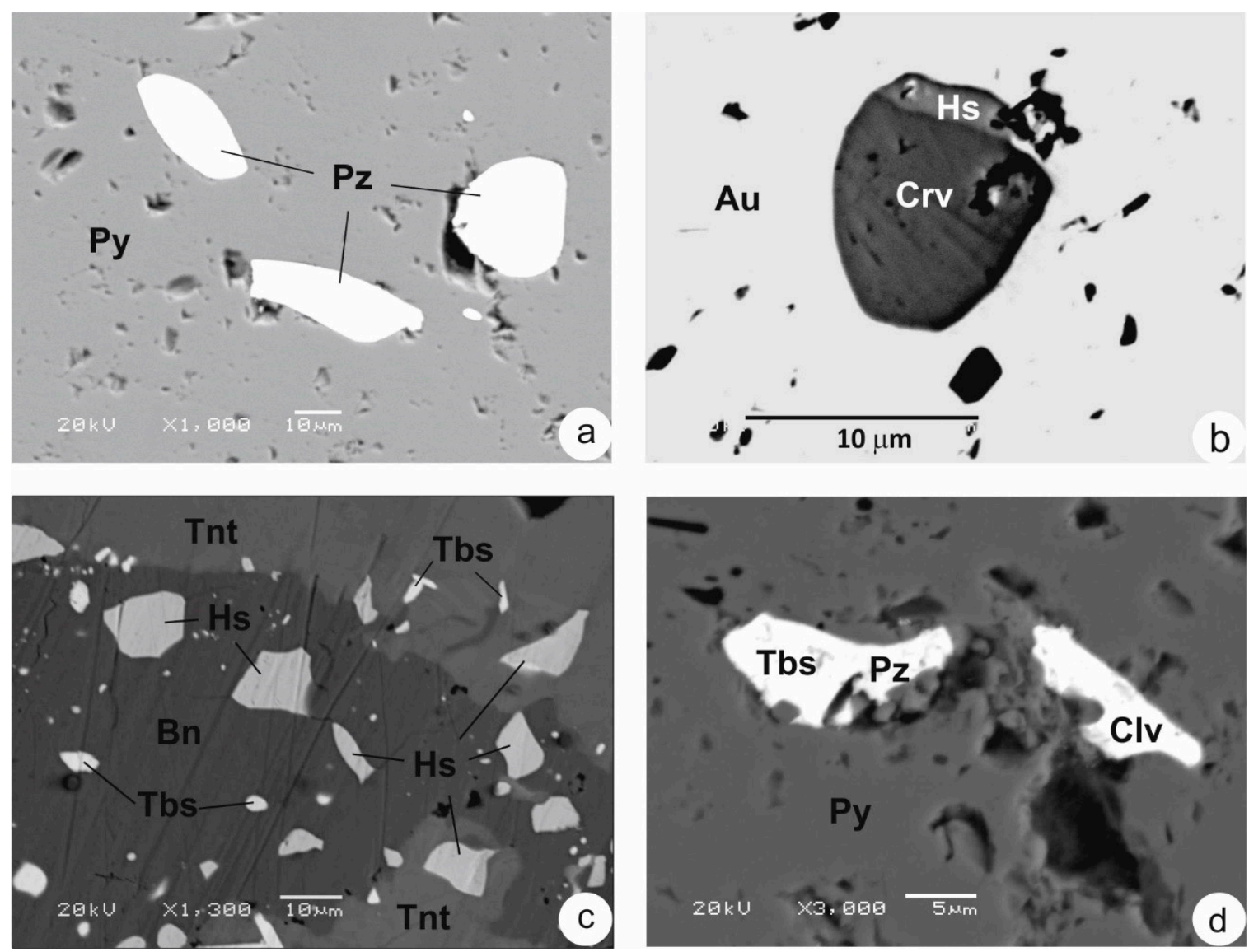

Figure 2. Au-Ag-Te mineralization: (a)—round-oval petzite (Pz) grains in pyrite (Py). Maiskoye ore field of the Tyrkandinsky cluster, (b) - grain of cervelleite (Crv) with hessite (Hs) rim in native gold (Au), Spokoinoye ore field of the Tyrkandinsky cluster, (c) - angular grains of hessite (Hs) and tellurobismuthite (Tbs) in the bornite (Bn)-tennantite (Tnt) matrix, Obman ore occurrence of the Nimgerkansky cluster, (d) - intergrowth of tellurobismuthite (Tbs) with petzite (Pz) and calaverite (Clv) grain in pyrite (Py), Granitnoye ore occurrence of the Nimgerkansky cluster.

\subsection{Typification of Telluride Mineralization}

The analysis of the species composition of Te minerals in the AS gold deposits allowed us to identify three mineral types: $\mathrm{Au}-\mathrm{Ag}-\mathrm{Te}, \mathrm{Au}-\mathrm{Bi}-\mathrm{Te}$, as well as the type, where the mineralization of both systems is combined and identified as a mixed one (Table 2).

\subsubsection{Au-Ag-Te Mineral Type}

The first type includes the deposits of the CAD-Kuranakhsky, Elkonsky, Yukhtinsky, and Dzhekondinsky fields, as well as the mineralization of the Upper-Tokkinsky cluster and the Khokhoy deposit of the Verkhneamginsky cluster. The Au-Ag-Te type is represented more often by petzite, hessite, and supergene Te minerals, and less often by coloradoite, altaite, and calaverite (Figure 2, Tables 3,5 and 6). Bi tellurides are absent, the exception is tellurobismuthite of the Podgolechnoye deposit, where it plays a subordinate role. The extensive and diverse list of associated minerals includes selenides (clausthalite ( $\mathrm{PbSe})$, naumannite $\left(\mathrm{Ag}_{2} \mathrm{Se}\right)$, tiemannite $\left.(\mathrm{HgSe})\right)$; sulfides (cinnabar $(\mathrm{HgS})$, stibnite $\left(\mathrm{Sb}_{2} \mathrm{~S}_{3}\right)$, orpiment $\left(\mathrm{As}_{2} \mathrm{~S}_{3}\right)$, acanthite $\left(\mathrm{Ag}_{2} \mathrm{~S}\right)$, uytenbogaardtite $\left.\left(\mathrm{Ag}_{3} \mathrm{AuS}_{2}\right)\right)$; $\mathrm{Ag}$ chlorides and bromides (chlorargyrite $(\mathrm{AgCl})$, bromargyrite $(\mathrm{AgBr})$ ); emphasizes the epithermal of $\mathrm{Au}-\mathrm{Ag}$-Te type ores. This mineral type also includes the low-temperature thallium mineralization of the Khokhoy deposit of the Verkhneamginsky cluster, represented by thallium tellurates and telluroantimonates with weissbergite $\left(\mathrm{TlSbS}_{2}\right)$, avicennite $\left(\mathrm{Tl}_{2} \mathrm{O}_{3}\right)$ and thallium antimonates (Table 7) [33,40]. A characteristic feature of ores bearing Au-Ag-Te mineralization is the susceptibility to supergene changes. In the ores of the Kuranakh deposit, the largest in AS, 
tellurides are represented exclusively by $\mathrm{Au}$ and $\mathrm{Au}-\mathrm{Ag}$ species (sylvanite predominates), Ag tellurides have not been identified. The minerals are characterized by a noticeable concentration of $\mathrm{Hg}$ and $\mathrm{Se}$, as well as a certain excess of Te in the composition (Table 3). The sulfides associated with them are characterized by an impurity of Te and a deficiency of S [14].
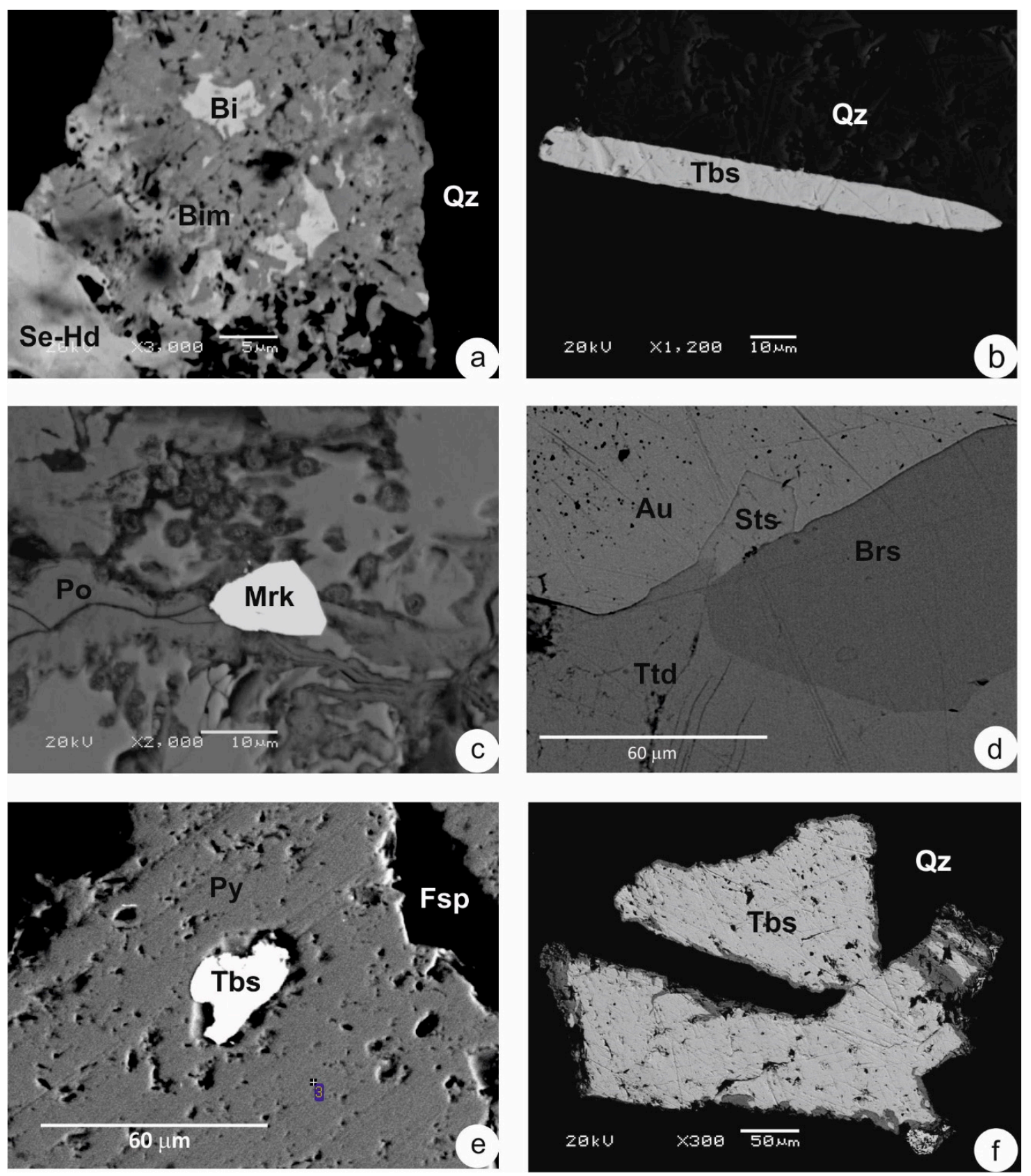

Figure 3. Au-Bi-Te mineralization: (a) — particles of native bismuth in bismuthinite (Bim) and Se-hedleyite (Se-Hd) grain in quartz $(\mathrm{Qz})$, the Bodorono deposit of the Verkhnealgominsky cluster, (b) - needle-shaped grain of tellurobismuthite (Tbs) in quartz (Qz), the Bodorono deposit of the Verkhnealgominsky cluster, (c)—merenskyite (Mrk) in вpyrrhotite (Po), the Dyvok ore occurrence of the Verkhnealgominsky cluster, (d)—the relationship of tetradymite (Ttd), bursaite (Brs), sulphotsumoite (Sts) and native gold $(\mathrm{Au})$, the Lagernoye ore occurrence of the Altan-Chaidakhsky ore cluster, (e)—grain of tellurobismuthite (Tbs) in pyrite (Py) among feldspar (Fsp), the Malenkoye ore occurrence of the Guvilgrinsky ore cluster, (f) - tabular grains of tellurobismuthite (Tbs) in quartz (Qz), the Khatyrkhay ore occurrence of the Verkhneamginsky ore cluster. 
Table 2. Types of telluride mineralization of the Aldan shield.

\begin{tabular}{|c|c|c|c|c|c|c|c|c|}
\hline Ore Node & Deposit, Ore Occurrence & Metasomatites & $\begin{array}{l}\text { Geochemical } \\
\text { Association }\end{array}$ & Te Minerals & $\begin{array}{c}\text { Associated } \\
\text { Minerals }\end{array}$ & $\begin{array}{l}\text { Fineness of } \\
\text { Native Gold }\end{array}$ & $\begin{array}{l}\text { Formation } \\
\text { Temperature }\end{array}$ & References \\
\hline \multicolumn{9}{|c|}{ Au-Ag-Te Mineral Type } \\
\hline \multirow[b]{2}{*}{ Kuranakhsky } & \multirow[b]{2}{*}{ Bokovoye and Delbe } & \multirow[b]{2}{*}{ Jasperoids } & $\begin{array}{c}\mathrm{Au}-\mathrm{Te} \text { in } \\
\text { pyrite-quartz } \\
\text { metasomatites }\end{array}$ & $\begin{array}{c}\text { Altaite, coloradoite, } \\
\text { petzite, krennerite, } \\
\text { calaverite, sylvanite }\end{array}$ & $\begin{array}{c}\text { Cinnabar, } \\
\text { arsenopyrite, stibnite }\end{array}$ & $700-900 \%$ & 200-150 & [14] \\
\hline & & & $\begin{array}{l}\text { Au-Te-Se and } \\
\text { Au-tellurates in } \\
\text { calcite veins }\end{array}$ & $\begin{array}{l}\text { Altaite, coloradoite, } \\
\text { petzite, kuranakhite, } \\
\text { yafsoanite, kuksite, } \\
\text { cheremnykhite, } \\
\text { V,Si-dugganite }\end{array}$ & $\begin{array}{c}\text { Clausthalite, } \\
\text { naumannite, } \\
\text { tiemannite, cinnabar, } \\
\text { orpiment, descloizite }\end{array}$ & $720-920 \%$ & $120-70$ & [13-17] \\
\hline Yukhtinsky & Samolazovskoye & Jasperoids & $\mathrm{Au}-\mathrm{Ag}-\mathrm{Te}$ & $\begin{array}{l}\text { Hessite, coloradoite, } \\
\text { calaverite }\end{array}$ & $\begin{array}{l}\text { Cinnabar, tiemannite, } \\
\text { acanthite, native } \mathrm{Ag} \text {, } \\
\text { sulvanite, roscoelite }\end{array}$ & & & {$[18,21,25,26]$} \\
\hline \multirow[t]{2}{*}{ Elkonsky } & Fedorovskoye (Lunnoye) & Gumbeites & $\mathrm{Au}-\mathrm{Ag}-\mathrm{Te}$ & $\begin{array}{l}\text { Te-canfieldite, hessite, } \\
\text { Ag sulphotelluride }\end{array}$ & $\begin{array}{c}\text { Native Ag, acanthite, } \\
\text { chlorargyrite, } \\
\text { bromargyrite, Ag-Tl } \\
\text { sulphosalts }\end{array}$ & & & [20-22] \\
\hline & $\begin{array}{c}\text { Ryabinovoye } \\
\text { (Muscovitoviy and Noviy) }\end{array}$ & Sericite-microcline & $\mathrm{Au}-\mathrm{Ag}-\mathrm{Te}$ & $\begin{array}{l}\text { Hessite, petzite, Pt-Pd } \\
\text { tellurides }\end{array}$ & Uytenbogaardtite & & & [21] \\
\hline Dzhekon-dinsky & Podgolechnoye & Sericite-microcline & $\mathrm{Au}-\mathrm{Ag}-\mathrm{Te}$ & $\begin{array}{l}\text { Hessite, petzite, } \\
\text { montbrayite, stutzite, } \\
\text { tellurobismuthite }\end{array}$ & Roscoelite & & & [24] \\
\hline \multirow[t]{2}{*}{ Verkhne-Tokkinsky } & Gross & Gumbeites & $\mathrm{Au}-\mathrm{Ag}-\mathrm{Te}$ & $\begin{array}{l}\text { Hessite, petzite, } \\
\text { Te-canfieldite }\end{array}$ & Acanthite & & & [29] \\
\hline & Tabornoye & Gumbaites & $\mathrm{Au}-\mathrm{Ag}-\mathrm{Te}$ & $\mathrm{Au}$ and $\mathrm{Ag}$ tellurides & & & & {$[28,29]$} \\
\hline Verkhneam-ginsky & Khokhoy & Jasperoids & $\mathrm{Au}-\mathrm{Te}-\mathrm{Sb}-\mathrm{Tl}$ & $\begin{array}{l}\mathrm{Tl} \text { tellurates and } \\
\text { telluroantimonates }\end{array}$ & $\begin{array}{c}\text { Weissbergite, } \\
\text { avicennite, acanthite, } \\
\text { chlorargyrite, } \mathrm{Tl} \\
\text { antimonates }\end{array}$ & $834-992 \%$ & & {$[32,33,40]$} \\
\hline \multicolumn{9}{|c|}{ Complex Au-Ag-Te-Bi Mineral Type } \\
\hline Lebedinsky & Lebedinoye, Radostnoye & Jasperoids & Au-Ag-Bi-Te & $\begin{array}{l}\text { Hessite, calaverite, } \\
\text { altaite, tetradymite }\end{array}$ & $\begin{array}{c}\text { Native } \mathrm{Ag}, \mathrm{Bi}, \\
\text { cinnabar, aikinite, } \\
\text { lillianite, bursaite, } \mathrm{Bi} \\
\text { tennantite-annivite, } \\
\text { tennantite, } \\
\text { arsenosulvanite }\end{array}$ & & & {$[19,41]$} \\
\hline
\end{tabular}


Table 2. Cont.

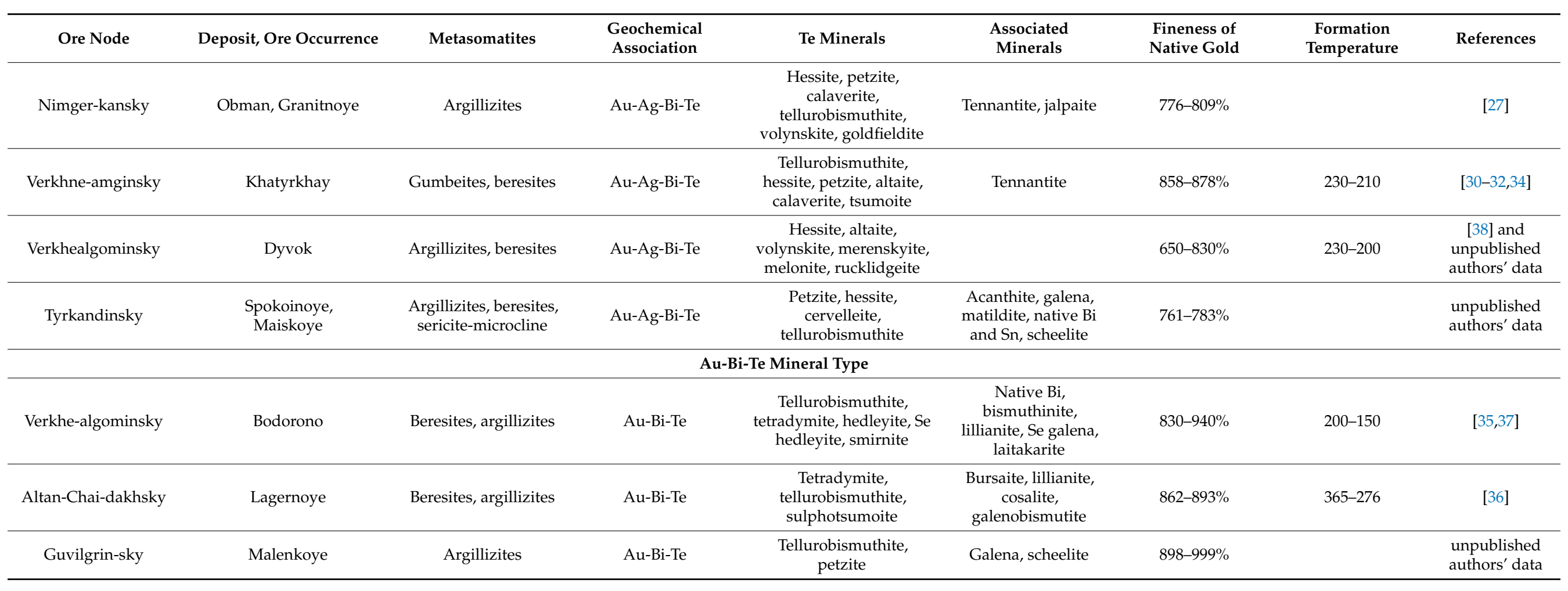


Table 3. Chemical composition of tellurides and sulfotellurides of $\mathrm{Au}, \mathrm{Ag}$ by EMP analysis.

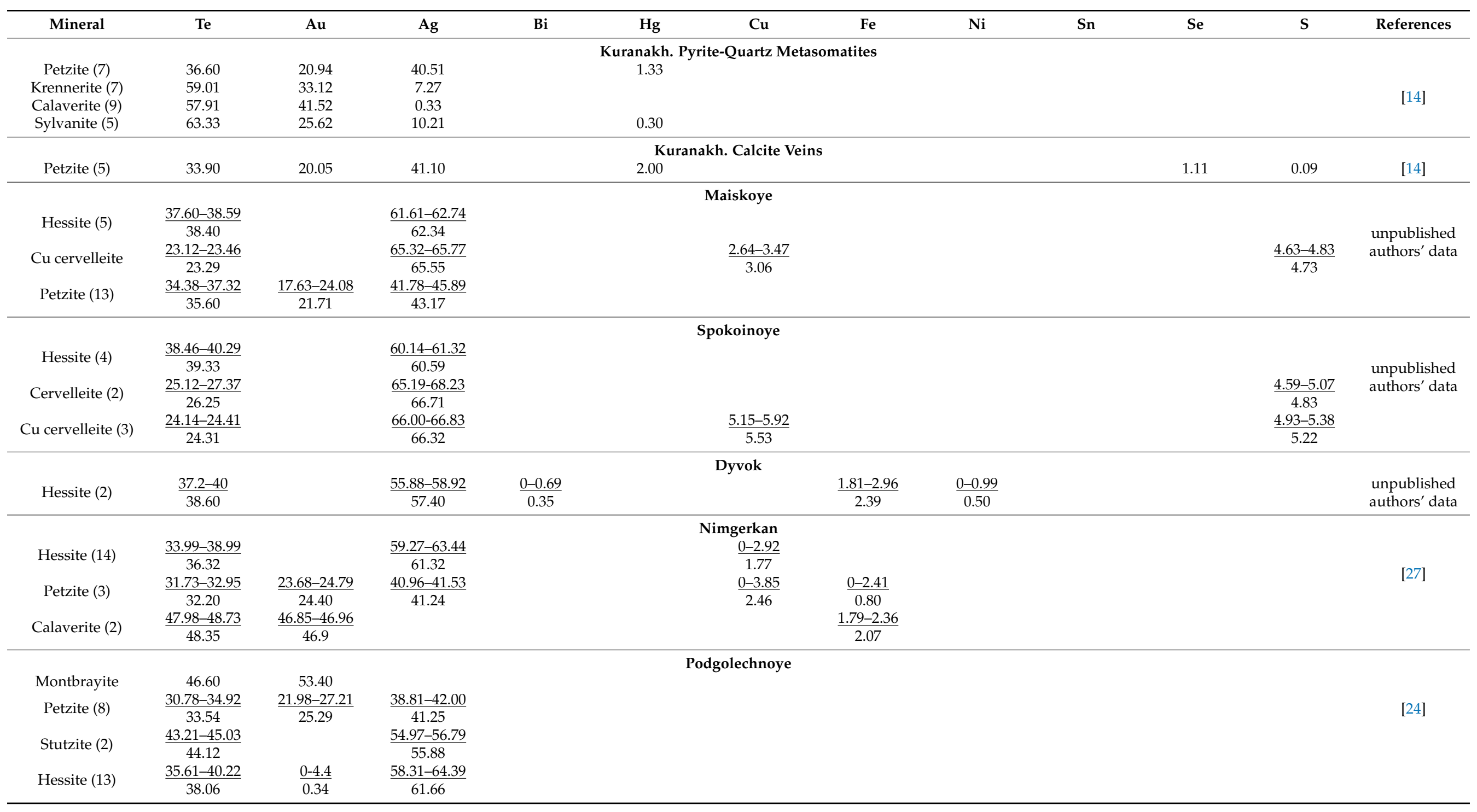


Table 3. Cont.

\begin{tabular}{|c|c|c|c|c|c|c|c|c|c|c|c|c|}
\hline Mineral & $\mathrm{Te}$ & $\mathrm{Au}$ & Ag & $\mathbf{B i}$ & $\mathrm{Hg}$ & $\mathrm{Cu}$ & $\mathrm{Fe}$ & $\mathrm{Ni}$ & Sn & Se & $S$ & References \\
\hline \multicolumn{13}{|c|}{ Lunnoye } \\
\hline Te-canfieldite (7) & $\frac{18.63-19.17}{18.96}$ & & $\frac{62.98-63.65}{63.40}$ & & & & & & $\frac{7.81-8.20}{801}$ & & $\frac{9.22-9.56}{0.42}$ & [22] \\
\hline \multicolumn{13}{|c|}{ Khatyrkhay } \\
\hline Petzite & 32.67 & 25.31 & 41.86 & & & & & & & & & \multirow{2}{*}{ [34] } \\
\hline Hessite & 34.62 & 4.91 & 60.71 & & & & 0.48 & & & & & \\
\hline
\end{tabular}

Note. The Tables $3-5$ and 7 above the line show the minimum and maximum values, below the line-the average value, in parentheses-the number of analyses.

Table 4. Chemical composition of tellurides and sulfotellurides Bi.

\begin{tabular}{|c|c|c|c|c|c|c|c|c|c|c|}
\hline Mineral & $\mathrm{Te}$ & Ag & $\mathrm{Bi}$ & $\mathrm{Pb}$ & $\mathrm{Cu}$ & $\mathrm{Fe}$ & $\mathrm{Sb}$ & Se & $\mathrm{S}$ & References \\
\hline \multicolumn{11}{|c|}{ Altan-Chaidakhsky } \\
\hline Tellurobismuthite (3) & $\frac{45.25-46.3}{45.72}$ & & $\frac{51.46-52.47}{51.98}$ & & & & & & & \multirow{6}{*}{ [36] } \\
\hline Tetradymite (19) & $31.63-35.14$ & $\underline{0-0.5}$ & $\underline{56.09-59.55}$ & $\underline{0-4.48}$ & & & & $\underline{0-0.2}$ & $\underline{4.67-5.34}$ & \\
\hline Pb-tetradymite (7) & $\underline{30.6-31.12}$ & 0 & $\underline{53.46-55.01}$ & $\underline{6.00-7.97}$ & & & & $\underline{0.02-0.15}$ & $\underline{5.64-5.84}$ & \\
\hline & 30.90 & (0) & 54.53 & 7.06 & & & & 0.09 & 5.72 & \\
\hline \multirow{2}{*}{ Sulphotsumoite (2) } & $21.57-22.64$ & $\underline{0-0.02}$ & $\underline{71.01-71.86}$ & $\underline{0.38-1.45}$ & & & & $\underline{0.07-0.08}$ & $2.98-3.19$ & \\
\hline & 22.11 & 0.01 & 71.44 & 0.92 & & & & 0.08 & 3.09 & \\
\hline \multicolumn{11}{|c|}{ Khatyrkhay } \\
\hline \multirow{3}{*}{ Tellurobismuthite (18) } & $\underline{47.36-49.67}$ & $\underline{0-0.30}$ & $\underline{49.27-52.17}$ & $\underline{0-0.08}$ & $\underline{0-0.11}$ & $\underline{0-0.09}$ & & & $\underline{0-0.03}$ & \multirow{4}{*}{ [32] } \\
\hline & 48.54 & 0.05 & 50.31 & 0.01 & 0.03 & $\overline{0.04}$ & & & $\overline{0.00}$ & \\
\hline & $\underline{36.53-37.50}$ & & $\underline{56.67-58.02}$ & $\underline{0-0.07}$ & $\underline{0-0.08}$ & $\underline{0.02-0.04}$ & & & $\underline{4.19-4.33}$ & \\
\hline Tetradymite (3) & 37.12 & 0.00 & 57.19 & 0.02 & 0.03 & 0.03 & & & 4.27 & \\
\hline Tsumoite (3) & $\frac{34.59-38.00}{35.75}$ & & $\frac{62.00-65.41}{64.25}$ & & & & & & & {$[30]$} \\
\hline \multicolumn{11}{|c|}{ Bodorono } \\
\hline Hedleyite & 19.71 & & 80.14 & & & & & & & \multirow{3}{*}{ [37] } \\
\hline $\mathrm{Se}$ & $\underline{13.77-16.59}$ & & $\underline{80.06-80.89}$ & & & & & $\underline{3.72-5.17}$ & & \\
\hline hedleyite (2) & 15.18 & & 8.47 & & & & & 4.44 & & \\
\hline \multicolumn{11}{|c|}{ Guvilgra } \\
\hline Tellurobismuthite & 48.4 & & 53.41 & & & & & & & $\begin{array}{l}\text { unpublished } \\
\text { authors' data }\end{array}$ \\
\hline
\end{tabular}


Table 4. Cont

\begin{tabular}{|c|c|c|c|c|c|c|c|c|c|c|}
\hline Mineral & Te & $\mathrm{Ag}$ & Bi & $\mathrm{Pb}$ & $\mathrm{Cu}$ & $\mathrm{Fe}$ & $\mathrm{Sb}$ & Se & $\mathrm{S}$ & References \\
\hline \multirow{3}{*}{ Tellurobismuthite (10) } & & & & & Nimgerkan & & & & & \multirow{5}{*}{ [27] } \\
\hline & $42.93-46.38$ & & $49.42-55.68$ & & $0-5.81$ & $0-2.65$ & & & & \\
\hline & 44.91 & & 52.57 & & $\overline{1.47}$ & $\overline{0.88}$ & & & & \\
\hline \multirow{2}{*}{ Volynskite (4) } & $\underline{40.01-42.35}$ & $\underline{18.02-20.58}$ & $\underline{32.11-36.30}$ & & $\underline{4.00-4.94}$ & $\underline{0-1.48}$ & & & & \\
\hline & 40.79 & 19.77 & 34.03 & & 4.44 & $\overline{0.37}$ & & & & \\
\hline \multicolumn{11}{|c|}{ Dyvok } \\
\hline Volynskite & 41.48 & 18.53 & 34.48 & 1.6 & & 2.69 & & & 0.69 & \multirow{2}{*}{$\begin{array}{l}\text { unpublished } \\
\text { authors' data }\end{array}$} \\
\hline Rucklidgeite & 47.35 & & 36.78 & 12.62 & & 4.49 & & & 0.59 & \\
\hline \multirow{3}{*}{ Tellurobismuthite (6) } & & & & & Maiskoye & & & & & \multirow{3}{*}{$\begin{array}{l}\text { unpublished } \\
\text { authors' data }\end{array}$} \\
\hline & $\underline{47.69-49.16}$ & & $\frac{51.17-52.60}{51.05}$ & & & & & & & \\
\hline & 48.21 & & 51.95 & & & & & & & \\
\hline \multirow[b]{2}{*}{ Tellurobismuthite (2) } & & & & & Podgolechnoye & & & & & \multirow[b]{2}{*}{ [24] } \\
\hline & $\frac{47.32-48.91}{48.00}$ & & $\frac{51.09-52.24}{52.00}$ & & & & & & & \\
\hline \multirow{3}{*}{ Tetradymite (2) } & & & & & Lebedinoye & & & & & \multirow{3}{*}{ [19] } \\
\hline & $\underline{34.66-35.44}$ & 0.03 & $\underline{58.13-58.85}$ & $\underline{0-0.61}$ & $\underline{0.08-0.18}$ & $\underline{0-0.03}$ & $\underline{0.25-0.33}$ & & $4.55-4.59$ & \\
\hline & 35.05 & 0.03 & 58.49 & 0.3 & 0.13 & 0.01 & 0.29 & & 4.57 & \\
\hline
\end{tabular}

Table 5. Chemical composition of $\mathrm{Pb}, \mathrm{Hg}$, $\mathrm{Pd}$ and $\mathrm{Cu}$ tellurides and sulfotellurides.

\begin{tabular}{|c|c|c|c|c|c|c|c|c|c|c|c|c|c|}
\hline Mineral & $\mathrm{Te}$ & Ag & Bi & $\mathrm{Pb}$ & $\mathrm{Hg}$ & $\mathrm{Cu}$ & $\mathrm{Fe}$ & As & $\mathrm{Ni}$ & Pd & Se & $\mathbf{S}$ & References \\
\hline \multicolumn{14}{|c|}{ Kuranakh. Pyrite-Quartz Metasomatites } \\
\hline Altaite & 39.64 & 0.52 & & 59.36 & & & & & & & & & \multirow{2}{*}[14]{} \\
\hline Coloradoite & 39.90 & & & 0.82 & 58.05 & & & & & & & & \\
\hline Altaite & 31.83 & & & 63.54 & & & & & & & 1.35 & 2.97 & \multirow{2}{*}{ [14] } \\
\hline Coloradoite & 38.58 & & & & 0.80 & & & & & & 1.00 & 0.11 & \\
\hline \multicolumn{14}{|c|}{ Dyvok } \\
\hline Merenskyite & 66.9 & & 5.44 & \multirow{3}{*}{60.25} & & & 1.05 & & 4.01 & \multirow[t]{3}{*}{24.55} & & & \multirow{3}{*}{$\begin{array}{l}\text { unpublished } \\
\text { authors' data }\end{array}$} \\
\hline Altaite & 37.2 & & & & & & 2.92 & & & & & \multirow[b]{2}{*}{2.58} & \\
\hline Melonite & 74.34 & & & & & & 4.22 & & 20.15 & & & & \\
\hline \multicolumn{14}{|c|}{ Nimgerkan } \\
\hline Goldfieldite (2) & $\underline{14.43-15.07}$ & & & & & $\underline{49.66-50.70}$ & $\underline{0-1.08}$ & $\underline{8.92-9.53}$ & & & & $\underline{26.14-26.58}$ & [27] \\
\hline & 14.75 & & & & & 50.18 & $\overline{0.54}$ & 9.23 & & & & 26.36 & {$[27]$} \\
\hline
\end{tabular}


Table 6. Chemical composition of supergene Te minerals of the Kuranakh deposit.

\begin{tabular}{|c|c|c|c|c|c|c|c|c|c|c|c|c|}
\hline Mineral & $\mathrm{TeO}_{3}$ & $\mathrm{ZnO}$ & $\mathrm{CaO}$ & $\mathrm{PbO}$ & $\mathrm{As}_{2} \mathrm{O}_{3}$ & $\mathrm{P}_{2} \mathrm{O}_{5}$ & $\mathrm{~V}_{2} \mathrm{O}_{5}$ & $\mathrm{Sb}_{2} \mathrm{O}_{5}$ & $\mathrm{SiO}_{2}$ & $\mathrm{MnO}$ & $\mathrm{H}_{2} \mathrm{O}$ & References \\
\hline Yafsoanite (crystals) (11) & 42.11 & 24.65 & 16.79 & 12.82 & & & & & 0.21 & & 2.02 & \multirow[b]{2}{*}[14]{} \\
\hline $\begin{array}{c}\text { Yafsoanite } \\
\text { (Concentric-zonal) (15) }\end{array}$ & 39.91 & 27.38 & 18.47 & 8.86 & & & & & 1.56 & & 2.77 & \\
\hline Kuksite (9) & 14.30 & 20.76 & 1.45 & 50.59 & & 10.38 & 1.81 & & 0.40 & & & \multirow{2}{*}[16]{} \\
\hline Cheremnykhite (10) & 13.76 & 18.89 & & 53.04 & 2.02 & & 9.25 & & 2.16 & & & \\
\hline V,Si-dugganite (8) & 14.15 & 18.33 & & 51.94 & 7.10 & & 4.30 & 0.25 & 2.37 & & 0.25 & [15] \\
\hline Kuranakhite & 38.20 & & & 45.40 & & & & & & 15.40 & & [13] \\
\hline
\end{tabular}


Table 7. Chemical composition of supergene Te minerals of the Khokhoy deposit.

\begin{tabular}{cccccc}
\hline Mineral & Te & Sb & Tl & O & References \\
\hline Tl tellurates (3) & $\frac{20.22-21.89}{21.00}$ & & $\frac{60.85-61.77}{61.29}$ & $\frac{17.24-17.45}{17.37}$ & unpublished \\
Tl telluroantimonates (4) & $\frac{6.00-6.91}{6.45}$ & $\frac{9.37-11.20}{10.30}$ & $\frac{65.25-67.50}{66.25}$ & $\frac{17.17-18.34}{17.73}$ & authors' data \\
\hline
\end{tabular}

\subsubsection{Au-Bi-Te Mineral Type}

The deposits of the Guvilgrinsky and Altan-Chaidakhsky clusters, as well as the Bodorono deposit of the Verkhnealgominsky cluster, are classified as the Au-Bi-Te type. $\mathrm{Bi}$ tellurides are developed here, mainly tellurobismuthite, less often hedleyite, and $\mathrm{Bi}$ sulfotellurides-tetradymite and sulphotsumoite (Figure 3, Table 2). The associated minerals are native $\mathrm{Bi}$, bismuthinite, $\mathrm{Pb}$ sulphobismuthites-lillianite $\left(\mathrm{Pb}_{3} \mathrm{Bi}_{2} \mathrm{~S}_{6}\right)$, bursaite $\left(\mathrm{Pb}_{5} \mathrm{Bi}_{4} \mathrm{~S}_{11}\right)$ and cosalite $\left(\mathrm{Pb}_{5} \mathrm{Bi}_{2} \mathrm{~S}_{5}\right)$. $\mathrm{Fe}, \mathrm{Cu}$, and $\mathrm{Pb}$ impurities in Te minerals are often related to the capture of the elements from matrix minerals-pyrite, pyrrhotite, galena, and chalcopyrite (Table 4). Note the presence of Se-containing hedleyite and associated laitakarite and Secontaining galena in the ores of the Bodorono deposit, as well as Pb-containing tetradymite in the Altan-Chaidakh deposit. A large role of lead is generally characteristic of the Au-Bi-Te type ores, as evidenced by the composition of the associated minerals.

\subsubsection{Mixed Au-Ag-Bi-Te Mineral Type}

The mixed-type deposits of the Lebedinsky, Nimgerkansky, Tyrkandinsky, and the Khatyrkhay ore occurrences of the Verkhneamginsky and Dyvok of the Verkhnealgominsky clusters contain minerals of both systems, and there are also single grains of such rare minerals as merenskyite, rucklidgite, and melonite in the ores of the Dyvok occurrence (Table 2) [38]. The associated minerals are diverse: native bismuth, galena, acanthite, scheelite, tin, and $\mathrm{Pb}$ sulfobismuthides-lillianite $\left(\mathrm{Pb}_{3} \mathrm{Bi}_{2} \mathrm{~S}_{6}\right)$, bursaite $\left(\mathrm{Pb}_{5} \mathrm{Bi}_{4} \mathrm{~S}_{11}\right)$ and aikinite $(\mathrm{PbCuBiS} 3), \mathrm{Ag}$ sulfobismuthide-matildite $\left(\mathrm{AgBiS}_{2}\right)$, as well as Bi-containing tennantiteannivite and tennantite. In the Te minerals of the Nimgerkan ore occurrence, $\mathrm{Cu}$ and $\mathrm{Fe}$ impurities are recorded, captured from the surrounding minerals-pyrite, tennantite, and bornite. A typical feature of the rare sulfotelluride $\mathrm{Ag}$, cervelleite, is an impurity of $\mathrm{Cu}$ up to $6 \mathrm{wt} \%$. The relationships of tellurides of both systems in the ores of the Nimgercansky cluster demonstrate their syngenenticity, expressed in the spatial combination of angular grains of tellurobismuthite and hessite without signs of substitution or intersection, as well as the facts of intergrowth of tellurobismuthite and petzite (Figure 2c,d).

\subsection{Gold Speciations}

Gold in the ores of the AS deposits is present in three varieties: invisible gold in pyrite, native gold, and gold in the composition of tellurides.

Studies of invisible gold by inductively coupled plasma mass spectrometry (LA-ICPMS) were carried out in pyrite from the Lunnoye, Samolazovskoye and Ryabinovoye deposits (the Muscovitoviy and Noviy sites) [21]. It is noted that the primary ores of the Lunnoye and Samolazovskoye deposits belong to refractory ores due to the significant amount of gold associated with sulfides. It is identified that pyrite from fine-grained aggregates is enriched with gold, as well as with $\mathrm{As}, \mathrm{Sb}, \mathrm{Hg}$, and $\mathrm{Tl}$ correlating with it, where its content at the Samolazovskoye field reaches $600 \mathrm{~g} / \mathrm{t}$, at the Lunnoye- $300 \mathrm{~g} / \mathrm{t}$, which exceeds the $\mathrm{Au}$ content in the coarser grained idiomorphic pyrite by two orders or higher. The dynamics of ablation shows a relatively uniform distribution of impurities in pyrite.

The average Au content in the pyrite of the Muscovitoviy ore occurrence of the Ryabinovoye deposit is only $0.14 \mathrm{~g} / \mathrm{t}$, the Noviy ore occurrence in the porous pyrite is 
about $0.96 \mathrm{~g} / \mathrm{t}$, and in the massive one, $0.06 \mathrm{~g} / \mathrm{t}$. $\mathrm{Cu}, \mathrm{Pb}$, and Te are characterized by topcut grades associated with inclusions of minerals that concentrated of the corresponding metals. The graph of changes in the contents of $\mathrm{Au}, \mathrm{Ag}$, and $\mathrm{Te}$ during ablation indicates that the noble metals are present as inclusions of native gold with an Ag impurity and Au and Ag tellurides. Gold in the porous pyrite of the Noviy site positively correlates with Ag and Te; no significant correlations were found for the pyrite of the Muscovitoviy site [21].

Native gold, which is associated with tellurides, is of a usually porous structure. Spongy and mustard gold is often found in Au-Ag-Te deposits (Figure 4) [14,33,41,42]. The grain size varies, and relatively large gold is typical for the Au-Bi-Te type. Native gold associated with $\mathrm{Au}-\mathrm{Ag}$-Te type minerals usually has a dimension from the dust to the fine class, while in the sypergene zone there is a noticeable increase in size of the gold. There are few data on the fineness of native gold, which is directly associated with Te mineralization (Table 2). The fineness of native gold ranges from 650 to $999 \%$. The comparison of the fineness of different types of telluride mineralization is complicated by the fact that postore supergene processes are widely developed in $\mathrm{Au}-\mathrm{Ag}$-Te ores, where Au refinement occurs. Nevertheless, the lower limits of the fineness of native gold of mineralization of the Au-Ag-Te type begin with 700\% [14], in the mixed type-range from 650 to $878 \%$ (excluding the ores of the Lebedinsky deposit, also subjected to the processes of supergene) and finally, in the Au-Bi-Te type, the fineness is $830-999 \%$. Thus, we can state a decrease in the fineness of native gold from the Au-Bi-Te type to the Au-Ag-Te. The decrease in the fineness of native gold is consistent with the sequence and temperatures of formation of Te minerals and associated mineral paragenesis from epithermal-mesothermal Au-Bi-Te (830-999\%) to the epithermal Au-Ag-Te (>700\%).

\subsection{Fluid Inclusions}

There is not much information on fluid inclusions (FI) in gold-telluride ores of AS. We studied the FI in the Au-Bi-Te the mineral type ores of the Bodorono (Verkhnealgominsky cluster) and Lagernoye (Altan-Chaidakhsky cluster) deposits, as well as the mixed Au-AgBi-Te type of the Dyvok ore occurrence (Verkhnealgominsky cluster).

Three types of inclusions were found in quartz from the gold-tellurium-bismuthquartz association of the Bodorono deposit: Type I-monophase aqueous inclusions; type II-two-phase gas-liquid inclusions, according to Raman spectroscopy data they contain $\mathrm{H}_{2} \mathrm{O}$ liquid and $\mathrm{CO}_{2}$ vapour. The homogenisation temperature is ranging from 145 to $200{ }^{\circ} \mathrm{C}$; type III-three-phase carbon dioxide-water inclusions $\left(\mathrm{H}_{2} \mathrm{Oliq}+\mathrm{CO}_{2} \mathrm{liq}+\mathrm{CO}_{2}\right.$ vap $)$ sometimes with impurities of $\mathrm{CH}_{4}$ and $\mathrm{N}_{2}$ vapour. The temperature of homogenisation of liquid $\mathrm{CO}_{2}$ into gas was $28-29{ }^{\circ} \mathrm{C}$. The density of liquid $\mathrm{CO}_{2}$ is $0.63-0.65 \mathrm{~g} / \mathrm{cm}^{3}$. The pressure is estimated at $0.4-0.6 \mathrm{kbar}$. Composition of the vapour phase (mol.\%): $\mathrm{CO}_{2} 95.2$, $\mathrm{N}_{2} 2.9, \mathrm{CH}_{4}$ 1.9. The formation temperature of the earlier gold-polymetallic assemblage is estimated at $270-300{ }^{\circ} \mathrm{C}$ [37].

FI data on the Dyvok ore occurrence suggest the formation of the early auriferous mineral assemblage (arsenopyrite-pyrite-quartz) at temperatures of $300-335^{\circ} \mathrm{C}$ and a pressure of $0.7 \mathrm{kbar}$. Studies of quartz from the middle gold-chalcopyrite-sphalerite assemblage showed homogenisation temperatures of $250-280^{\circ} \mathrm{C}$. The latest quartz-telluride association is characterised by an average homogenisation temperature of $210-230^{\circ} \mathrm{C}$.

Microthermometric studies of the FI of the Altan-Chaidakh ore cluster have determined that the formation of the gold-polymetallic assemblage occurred at temperatures of 300-331 ${ }^{\circ} \mathrm{C}$ from $\mathrm{Mg}, \mathrm{Cl}$-solutions, with $\mathrm{CO}_{2}$ and impurities of $\mathrm{CH}_{4}$ in the vapour phase. The gold-tellurium-bismuth assemblage was formed at close temperature values $\left(276-365^{\circ} \mathrm{C}\right)$ from $\mathrm{Mg}-\mathrm{Na}-\mathrm{KCl}$ - solutions with a predominant $\mathrm{CO}_{2}$ content in the vapour phase. 

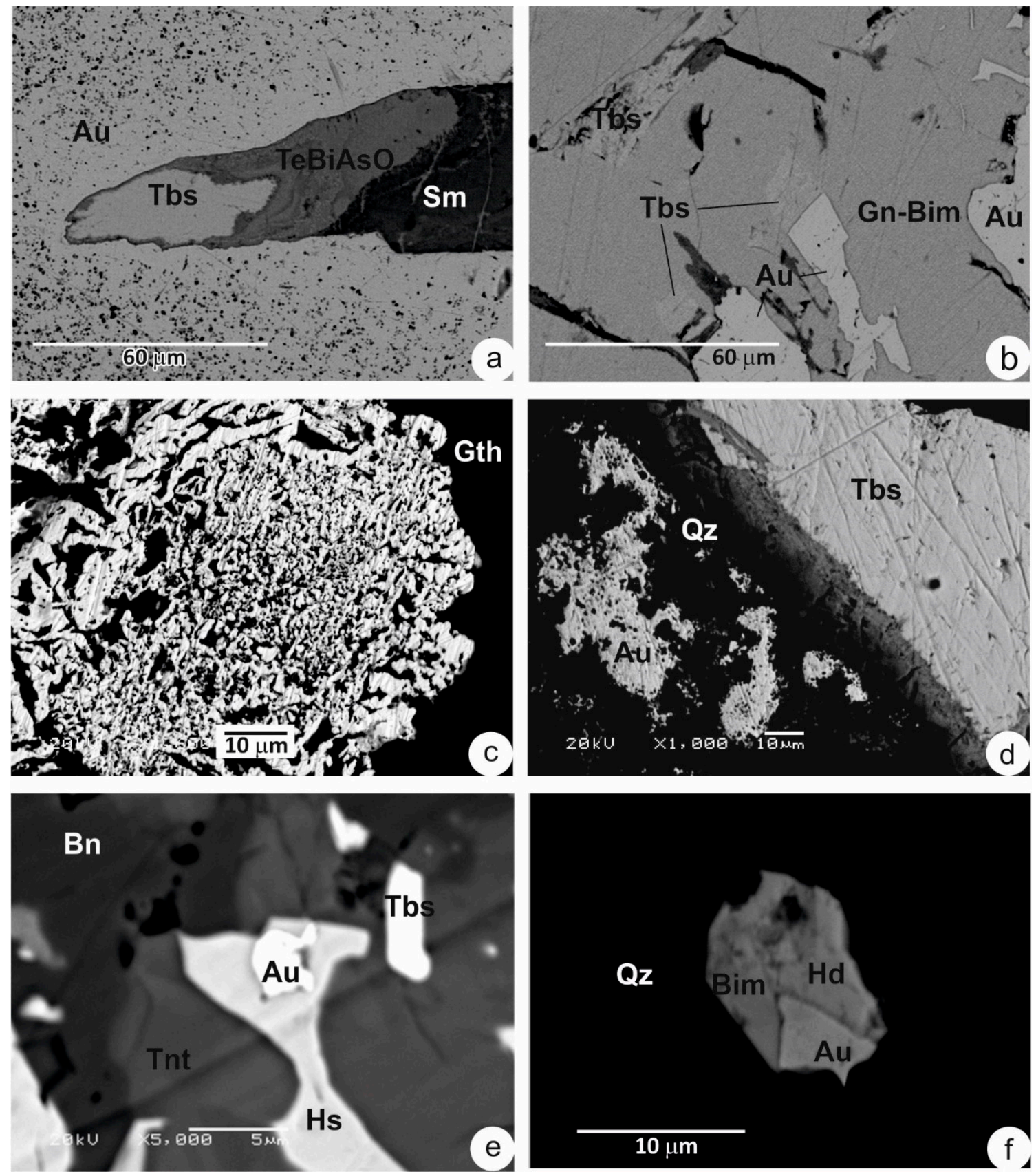

Figure 4. Native gold: (a)—substitution of tellurobismuthite (Tbs) for smirnite ( $\mathrm{Sm}$ ) and tellurates (TeBiAsO) in porous gold $(\mathrm{Au})$, the Lagernoye ore occurrence of the Altan-Chaidakhsky ore cluster, (b) - replacement of platy grains of tellurobismuthite (Tbs) for native gold $(\mathrm{Au})$ in galenobismutite (Gn-Bim), the Lagernoe ore occurrence of the Altan-Chaidakhsky ore cluster, (c)—spongy gold in goethite (Gth), the Khokhoy ore occurrence of the Verkhneamginsky ore cluster, (d)—porous gold $(\mathrm{Au})$ and tabular grain of tellurobismuthite $(\mathrm{Tbs})$ in quartz $(\mathrm{Qz})$, the Khatyrkhay ore occurrence of the Verkhneamginsky ore cluster; (e) - native gold ( $\mathrm{Au})$ in hessite (Hs) and tellurobismuthite (Tbs) grain in bornite (Bn)-tennantite (Tnt) matrix, the Obman ore occurrence of the Nimgercansky ore cluster, (f)—the relationship of native gold (Au), bismuthinite (Bim) and hedleyite $(\mathrm{Hd})$ in quartz $(\mathrm{Qz})$, the Bodorono deposit of the Verkhnealgominsky cluster.

The ore mineralization of quartz-chlorite-feldspar metasomatites of the Khatyrkhay ore occurrence in the Verkhneamginsky region, represented by two assemblages, was studied by I.Prokopyev (2019). The first association represented by sulfide minerals: pyrite, chalcopyrite, galena, sphalerite, molybdenite, boulangerite, etc. is formed from highly concentrated (44-22 wt.\% NaCl-eq.) of fluid $\mathrm{CO}_{2} \pm \mathrm{N}_{2}$ solutions at temperatures 
of $330-400{ }^{\circ} \mathrm{C}$ and at a pressure of 1150 bar. The late gold-telluride ore mineralization was formed from low-concentrated (3.3-9.2 wt.\% NaCl-eq.) of fluid $\mathrm{CO}_{2}$ solutions at temperatures of $210-230{ }^{\circ} \mathrm{C}$ [34].

Pressure-Temperature (P-T) parameters of the formation of the Lebedinoye deposit were studied in quartz of different paragenesis of the first (tremolite-quartz-magnetitesulfide) and second (quartz-carbonate-gold-bismuth-sulfide) stages (Orekhovaya and Vodonosnaya deposits) [19]. The results of studies of ore mineralization of the Orekhovaya deposit showed that the temperatures of fluid homogenisation in tremolite are $342-316^{\circ} \mathrm{C}$, quartz, which is in the same paragenesis with tremolite, $321^{\circ} \mathrm{C}$. $\mathrm{T}_{\text {hom }}$ of inclusions in later quartz generations decreases: $284-223{ }^{\circ} \mathrm{C}$ and $195-157^{\circ} \mathrm{C}$. Pressure- $570-440$ bar. The study of fluid inclusions in quartz of ore samples of the Vodonosnaya deposit shows $\mathrm{T}_{\text {hom }}$ of fluid inclusions of $500-484{ }^{\circ} \mathrm{C}$, pressure- $2040-1260$ bar. $\mathrm{T}_{\text {hom }}$ values of inclusions of later quartz generations are close to the quartz temperatures in ore samples of the Orekhovaya ore deposit, but the pressure values vary significantly from 450 to 3180 bar.

High salt concentrations (46.9-51.5 wt.\% NaCl-eq.) obtained at $\mathrm{T}_{\text {hom }} 186-162{ }^{\circ} \mathrm{C}$ and a pressure of $2250-2130$ bar. In other samples, at $\mathrm{T}_{\text {hom }} 339-310^{\circ} \mathrm{C}, 231^{\circ} \mathrm{C}, 177-136^{\circ} \mathrm{C}$ and a pressure drop (1530-640 bar), the salt concentration decreases and is 10.9-6.2, 9.2 and $1.2-0.5$ wt.\% NaCl-eq. [19].

According to the results of the study of FI at the Kuranakh deposit, the temperature of formation of the early quartz-pyrite assemblage with fine-grained quartz 1 and finelydispersed gold in pyrite is $350-200{ }^{\circ} \mathrm{C}$, quartz-polysulfide assemblage with pyrite and riziform quartz 2 and visible gold-250-200 ${ }^{\circ} \mathrm{C}$. The formation of Au-Ag-Te mineralization in quartz veins occurs at temperatures of $220-150{ }^{\circ} \mathrm{C}$, and the Au-Te-Se and Au-tellurate mineralization in calcite veins decreases to $120-70{ }^{\circ} \mathrm{C}$. Thus, there is a regressive regime of the ore formation process with temperature inversions in the range of $50-100{ }^{\circ} \mathrm{C}$, as well as a change in mineral assemblages [14].

\section{Discussion}

The Aldan alkaline volcanogenic-intrusive complex was formed in several stages [5] In the first stage (Late Triassic-Early Jurassic), sills of quartz porphyry, orthophyre, and nordmarkite were intruded into the platform cover, accompanied on the surface by domes and trachyte covers. In the second stage (Middle-Late Jurassic), concentric-zonal plutons of platinum-bearing dunites, wehrlites, and gabbroids were formed, followed by alkaline volcanic plutons, stocks, dikes of alkaline gabbroids and syenites, and their effusive analogues (alkaline trachytes, pseudoleucitic phonolites). In the third stage (Late Jurassic-Early Cretaceous), laccoliths, stocks, dikes of monzonites, subalkaline syenites, and granosyenites were intruded. In the fourth stage (Late Cretaceous), the stocks of aegirine granites and regional dike belts of syenite-porphyry, orthophyre, minette, bostonite, and picrite were formed.

The formation of the Aldan alkaline volcanogenic-intrusive complex involved metasomatic changes in rocks. In the Central Aldan region, four metasomatic formations are goldproducing: gumbaite, sericite-microcline metasomatites, jasperoid and argillizited [5,11].

The gold mineralization of AS is diverse. The metasomatites of the gumbaite formation are represented by pyrite-carbonate-K-feldspar metasomatites, which are related to the main gold-uranium deposits of the Elkonsky ore cluster. Gold-copper-porphyry (Ryabinovsky) type of mineralization, including veined-disseminated sulfide mineralization in alkaline volcanic plutons (Ryabinovoye and Noviy deposits) is associated with the formation of sericite-microcline metasomatites. The jasperoid type of mineralization is represented by deposits formed in three geostructural settings: in the contact zones of the Mesozoic alkaline and subalkaline intrusions with carbonate rocks of the Vendian among hydrothermally altered dolomite marbles, magnesian skarns and syenites (Samolazovsky subtype); in zones of layered and transverse fracturing in the Vendian-Lower Cambrian carbonate rocks (Lebedinsky subtype) and at the contact of Lower Cambrian limestones with Jurassic sandstones (Kuranakhsky subtype). Gold-argillizited mineralization of the 
Nimgerkansky type is spatially confined to the intrusions of syenite-porphyry of Cretaceous age and is associated with crystal-bearing and amethyst-bearing mineralization [11].

The systematization of Te mineralization demonstrates its presence in all available types of ore-bearing metasomatites, that indicates a regional large-scale manifestation in the area of AS. The process of ore formation is long, multi-stage, but in general, three producing stages are distinguished in most deposits-the early pyrite-quartz assemblage with finelydispersed gold is replaced by (gold)-polysulfide-quartz and ends with gold-telluride.

The typification of gold mineralization on Te minerals and mineral assemblages revealed a certain zoning in the location of gold deposits on the area of AS. In general, the Aldan-Stanovoy Shield is characterized by zoning in the distribution of the Mesozoic magmatism derivatives. The Stanovoy geoblock is characterized by granitoid intrusions, while the Aldan geoblock mainly by subalkaline and alkaline ones. When considering the position of objects with Au-Ag-Te and Au-Bi-Te mineralization, zoning is traced, which is consistent with the distribution of derivatives of the Mesozoic magmatism. Au-Bi-Te mineralization is typical for deposits that are close to the Stanovoy plutonogenic region in the areas of dikes and small intrusions of acid composition in the Guvilgrinsky (granodiorites), Verkhnealgominsky (diorite porphyrites), and Altan-Chaidakhsky (granodiorites, diorite porphyrites, dacites) clusters. Au-Ag-Te mineralization is developed in the northern and central parts of the Aldan geoblock, where massifs of rocks of mainly subalkaline and alkaline composition were formed.

Lateral zoning is also observed in the distribution of mineralization types in the CAD area: mixed Au-Ag-Bi-Te mineralization with predominance of $\mathrm{Bi}$ is developed in ores of the Lebedinsky cluster, located in the center of the magmatogenic structure, where the most intense magmatism in the CAD occurs, covering all 4 stages of igneous activity, and mixed and the Au-Ag-Te ores in the Kuranakh and Yukhtin jasperoids, the Elkon and Jekondin gumbeites are developed on the periphery at a distance of 10-30 km.

Available data on the temperatures of formation of Au-Te mineralization (Table 2), as a rule, show their epithermal. Thus, the formation of the Au-Te mineralization of the Kuranakhsky cluster in quartz veins occurs at temperatures of $220-150{ }^{\circ} \mathrm{C}$, and in calcite veins it decreases to $120-70{ }^{\circ} \mathrm{C}$ [14]. Au-Bi-Te mineralization can classed as the epithermalmesothermal, the highest temperature of ore formation is shown by the mineralization of the Altan-Chaidakhsky cluster-365-276 ${ }^{\circ} \mathrm{C}$. The Bodorono deposit, judging by the presence of Se-containing hedleyite and galena, as well as laitakarite and the formation temperature of $200-150^{\circ} \mathrm{C}$, has features of epithermal mineralization.

High-temperature inclusions of the Lebedinoye deposit with mixed Au-Ag-Bi-Te mineral type probably belong to the period of scarification, which strengthens the argument in favor of the connection of the hydrothermal process with magmatism. At the same time, the high pressure of ore-forming fluids may indicate a significant depth of the source. The large range of variations in salt concentrations may be due to the presence of two sources of ore-forming fluids: one is associated with dilute solutions, and the other with brines, the concentration of salts in which decreases with a drop in pressure. The data obtained indicate the heterogeneity of ore-bearing solutions, their connection with magmatism, the depth of formation of hearths in each specific deposit, and different sources of ore-forming hydrothermal solutions [19].

Te ores of the AS are characterized by a number of properties typical for the epithermal alkaline gold-telluride type (A-type). This was previously shown by Leontiev for the Samolazovskoye and Podgolechnoye deposits $[24,26]$. The characteristic features of A-type deposits are a close spatial relationship with alkaline magmatism, and a typical "mantle" association of elements (Te, V, and F), an important role in the minerals of $\mathrm{Au}$ and $\mathrm{Ag}$ tellurides, fluorite and vanadium-containing minerals (roscoelite, descloizite, sulvanite, arsenosulvanite, cheremnykhite and dugganite) $[43,44]$. Examples of A-type deposits are world-class facilities such as Cripple Creek (Colorado, USA, $673 \mathrm{t} \mathrm{Au}$ ), Acupan (Philippines, $500 \mathrm{t} \mathrm{Au}, 500 \mathrm{t} \mathrm{Ag}$ ), Emperor (Fiji, >120 t Au), Ladolam (Papua New Guinea, $680 \mathrm{t} \mathrm{Au}$ ), Kochbulak (Uzbekistan), etc. 
The Kuranakh and Khokhoy deposits have features of Carlin-type mineralization: they are located in the area of tectonic-magmatic activation, are conjugated with intrusions of monzonite-granodiorite series, and are of normal and high alkalinity, strata of carbonate rocks, stratoidal disseminated deposits, presence of jasperoids, low content of sulfides, finely-dispersed gold in pyrite, typomorphic elements-Au-Tl-As-Hg-Sb-Te-Ba-F [4,33,40].

Numerous studies show the presence of gold of three varieties: invisible in pyrite or arsenopyrite, native gold and gold tellurides. With the advent in recent decades of the highly sensitive inductively coupled plasma mass spectrometry (LA-ICP-MS) method and, especially, the local version of this method with laser ablation of the substance directly from the sample, it became possible to determine gold and other trace elements in pyrite [45-49].

The gold and tellurium studies of the Emperor deposit [45] showed that gold is found in three different forms: as "invisible" or submicrometer-size inclusions of gold and tellurium in arsenian pyrite, as visible native gold and tellurium, and as tellurides. The pyrite from Emperor is among the most Au-(up to 11,057 ppm Au), Te-(up to 5796 ppm Te), and As-rich (up to $16.60 \mathrm{wt} \%$ As) yet reported from any mineral deposit type.

In addition, Large, and Maslennikov (2020) [47] report a distinct chemical association of invisible gold in pyrite in the deposits studied. For example, in the Gold Quarry (Carlin type), Mt Olympus, Macraes and Konkera, the invisible gold is principally related to the arsenic content of pyrite. In contrast, in Kumtor and Geita Hill, the invisible gold is principally related to the tellurium content of pyrite. Other deposits (Golden Mile, Bendigo, Spanish Mountain, Witwatersrand Carbon Leader Reef (CLR)) exhibit both the Au-As and $\mathrm{Au}$-Te association in pyrite. Some deposits of the Au-As association have late orogenic Au-As-rich rims on pyrite, which substantially increase the value of the ore. In contrast, deposits of the Au-Te association are not known to have Au-rich rims on pyrite but contain nano- to micro-inclusions of $\mathrm{Au}-\mathrm{Ag}-(\mathrm{Pb}-\mathrm{Bi})$ tellurides.

As a result of the studies conducted by Belogub [21] at the deposits of the Aldan Shield, it was found that fine-grained aggregates of iron disulfides are significantly enriched with impurities compared to idiomorphic pyrite. This may be due to both the higher growth rate of fine-grained aggregates and their more significant specific surface area, which contributes to the capture of impurities, and the defectiveness of the disulfides themselves, which contain submicron or nano-inclusions of minerals that concentrate of impurities, since the association of impurities observed for fine-grained aggregates of iron disulfides, in general, corresponds to the set of rare mineral species found in ores. In larger idiomorphic crystals, the impurity content is significantly lower, that is related to a lower growth rate, which does not contribute to the capture of incoherent (non-structural) impurities.

Au-Ag tellurides are important accessory minerals, carrying a significant proportion of the gold endowment in some low to medium temperature hydrothermal vein deposits [50]. At the Kochbulak and Kairagach deposits (Uzbekistan) [51-55], Golden Mile in Kalgoorlie, Western Australia [56] about 20\% of Au is in telluride form, Cripple Creek, [57]; Emperor, Fiji-10-50\% in the form of tellurides [58]; and Săcărîmb, Romania [59], at the Bereznyakovskoye deposit (S.Ural) about $80 \%$ of gold [60], Sandaowanzi [61] more than $95 \%$ of the extracted gold occurs in the form of tellurides. We assume that the tellurides of the gold deposits of the Aldan Shield are also an additional source of at least $20 \%$ of the total gold reserve.

The mechanism of formation of native gold from gold and silver tellurides was experimentally shown in the works [62-65]. The formation of spongy gold as a result of the decomposition of maldonite under supergene conditions was considered in studies [66,67] and hypogenic [68-73]. The porous gold in the studied ores is also the result of the decomposition of tellurides, as we have shown by the example of native gold from the Khokhoy deposit of the Verkhneamnginsky node [33]. Thus, the Au-Ag-Bi-Te minerals are one of the most important sources of gold in the world. 


\section{Conclusions}

Systematization and generalization of published and original data on Te mineralization enables us to demonstrated a wide variety of mineral species and significantly expand the territory of distribution of Au-Te mineralization, which indicates its large-scale regional occurrence in the Aldan Shield. At the same time, tellurium minerals are developed in all known types of metasomatic formations. Gold is not only in an invisible state in sulfides and in the form of native particles of different fineness, but is also part of a variety of compounds: montbrayite $\left(\mathrm{Au}_{2} \mathrm{Te}_{3}\right)$, calaverite $\left(\mathrm{AuTe}_{2}\right)$, sylvanite $(\mathrm{AuAg})_{2} \mathrm{Te}_{4}$, krennerite ( $\mathrm{AuAgTe}$ ) and petzite $\left(\mathrm{Ag}_{3} \mathrm{AuTe}\right.$ ). $\mathrm{Au}$-Ag-Bi tellurides are important accessory minerals containing a significant proportion of the gold reserve.

Author Contributions: L.A.K. and G.S.A. conceived and designed the study, the paper, provided field work on gold deposits, provided valuable insights, interpreted the results, and wrote the paper. V.N.K. provided field work on gold-ore objects, performed mineralogical description and photographing of polished sections, conducted microthermometric studies. All authors have read and agreed to the published version of the manuscript.

Funding: The research was carried out within the framework of the state task of the Diamond and Precious Metals Geology Institute of the Siberian Branch of the Russian Academy of Sciences, funded by the Ministry of Science and Higher Education of the Russian Federation, project No 0381-20190004 and supported by grants of the Russian Foundation for basic Research No 18-45-140045 and No 19-35-90051.

Institutional Review Board Statement: Not applicable.

Informed Consent Statement: Not applicable.

Data Availability Statement: Not applicable.

Acknowledgments: The authors thank N. Khristoforova, S. Popova, and S. Karpova for their help in carrying out a large amount of work on the scanning electron microscope and X-ray spectral microanalyzer (Diamond and Precious Metals Geology Institute of the Siberian Branch of the Russian Academy of Sciences), V. Bocharov for his help using the Raman Spectroscopy (Saint Petersburg State University) and E. Sokolov for the organization of field work at gold mining facilities (JSC "Yakutskgeologiya") and for discussing the results of the research. The authors are grateful to anonymous reviewers for their comments and constructive suggestions.

Conflicts of Interest: The authors declare no conflict of interest.

\section{References}

1. Bilibin, Y. Fundamentals of Placer Geology; State United Scientific and Technical Publishing House: Moscow, Russia, 1938; 504p. (In Russian)

2. Petrovskaya, N.V.; Fastolovich, A.I. Nature of mineralization in Lebedinoe gold deposit (Aldan). Sov. Geol. 1940, 2-3, 54-65. (In Russian)

3. Petrovskaya, N.V.; Kazarinov, A.I. Gold deposits of the Central Aldan. In Geology of the Main Gold Deposits of the USSR; TsNIGRI: Moscow, Russia, 1951; Volume 2, 154p.

4. Vetluzhskikh, V.G.; Kim, A.A. Geological and commercial types of gold deposits in Southern Yakutia. Otechestvennaya Geol. 1997, 1, 16-24. (In Russian)

5. Ugriumov, A.N.; Dvornik, G.P. Altered formations and gold mineralization in the ore region of the Mesozoic tectonic-magmatic activation (Aldan Shield). Proc. Ser. Geol. Geophys. 2000, 10, 119-128. (In Russian)

6. Vetluzhskikh, V.G.; Kazansky, V.I.; Kochetkov, A.Y.; Yanovskiy, V.M. Central Aldan gold deposits. Geol. Ore Depos. 2002, 44, 405-434.

7. Kazansky, V.I. The unique Central Aldan gold-uranium ore district (Russia). Geol. Ore Depos. 2004, 46, 167-181.

8. Kochetkov, A.Y. Mesozoic gold-bearing ore-magmatic systems of the Central Aldan. Geol. Geophys. 2006, 47, 850-864. (In Russian)

9. Boitsov, V.E.; Pilipenko, G.N.; Dorozhkina, L.A. Gold and gold-uranium deposits of Central Aldan. In Proceedings of the Large and Superlarge Deposits of Ore Minerals; Strategic Types of Ore Raw Materials; IGEM RAS: Moscow, Russia, 2006; Volume 2, pp. 215-240. (In Russian)

10. Maksimov, E.P.; Uyutov, V.I.; Nikitin, V.M. The Central Aldan gold-uranium ore magmatogenic system, Aldan-Stanovoy shield, Russia. Russ. J. Pac. Geol. 2010, 4, 95-115.

11. Dvornik, G.P. Gold-ore metasomatic formations of the Central Aldan region. Lithosphere 2012, 2, 90-105. (In Russian) 
12. Molchanov, A.V.; Terekhov, V.V.; Shatov, V.V.; Petrov, O.V.; Kukushkin, K.A.; Kozlov, D.S.; Shatova, N.V. Gold ore districts and ore clusters of the Aldanian metallogenic province. Reg. Geol. Metallog. 2017, 71, 93-111. (In Russian)

13. Yablokova, S.V.; Dubakina, L.S.; Dmitrak, A.L.; Sokolova, T.V. Kuranakhite-New hypergenic mineral of tellurium. Zap. Vsesoyuznogo Mineral. Obs. 1975, 3, 310-313. (In Russian)

14. Kim, A.A. Gold-telluride-selenide mineralization in the Kuranakh deposit (Central Aldan). Zap. Vserossiyskogo Mineral. Obs. 2000, 5, 51-57. (In Russian)

15. Kim, A.A.; Zayakina, N.V.; Lavrent'yev, Y.G. Yafsoanite, $\left(\mathrm{Zn}_{1.38} \mathrm{Ca}_{1.36} \mathrm{~Pb}_{0.26}\right)_{3} \mathrm{TeO}_{6}$, a new tellurium mineral. Zapiski Vsesoyuznogo Mineral. Obshchestva 1982, 111, 118-121. (In Russian)

16. Kim, A.A.; Zayakina, N.V.; Lavrentiev, Y.G.; Makhotko, V.F. Si-variety of dugganite-The first find in the USSR. Mineral. J. 1988, 10, 85-89. (In Russian)

17. Kim, A.A.; Zayakina, N.V.; Makhotko, V.F. Kuksite $\mathrm{Pb}_{3} \mathrm{Zn}_{3} \mathrm{TeO}_{6}\left(\mathrm{PO}_{4}\right)_{2}$ and cheremnukhite $\mathrm{Pb}_{3} \mathrm{Zn}_{3} \mathrm{TeO}_{6}\left(\mathrm{VO}_{4}\right)_{2}-\mathrm{New}$ tellurates from the Kuranakh gold deposit (Central Aldan, Southern Yakutia). Zap. Vsesoyuznogo Mineral. Obs. 1990, 5, 50-57. (In Russian)

18. Eluev, V.K.; Kiskin, V.A.; Kislyi, A.V. Report on the Results of the Detailed Exploration of the Samolazovskoe Gold Deposit Conducted in 1999-2000; Book I. The Text of the Report; Aldan, Russia, 2000, Unpublished work.

19. Dobrovolskaya, M.G.; Razin, M.V.; Prokofiev, V.Y. The Lebedinoe gold deposit (Central Aldan): Mineral paragenesis, stages and conditions of formation. Geol. Ore Depos. 2016, 58, 308-326. [CrossRef]

20. Grechishnikov, D.N.; Krajyshkin, S.A.; Bugrova, N.S. Russia, 2013 Report on the Completed Exploration Work at the Lunnoe Field for 2008-2013 with the Estimation of Reserves as of 01.01.2013. Unpublished work.

21. Belogub, E.V.; Novoselov, K.A.; Artemyev, D.A.; Palenova, E.E. Trace contaminations of pyrite from the Elkonsky and Ryabinovsky types of gold deposits in the Central Aldan ore region (Sakha-Yakutia). Metallog. Anc. Mod. Oceans 2018, 1, 146-150. (In Russian)

22. Novoselov, K.A.; Belogub, E.V.; Blinov, I.A. Te-canfieldite from ores of the Lunnoe Au-U deposit (Aldan region, Republic Sakha of Yakutia). Mineralogy 2019, 5, 49-56. (In Russian)

23. Leont'ev, V.I.; Platonova, N.V. Features of the occurrence of gold mineralization of the Lebedinsky type in the Dzhekondinsky ore cluster (Central Aldan ore region). Reg. Geol. Metallog. 2016, 65, 84-92. (In Russian)

24. Leont'ev, V.I.; Bushuev, Y.Y. Ore mineralization in adular-fluorite metasomatites: Evidence of the Podgolechnoe alkalic-type epithermal gold deposit (Central Aldan Ore District, Russia). Key Eng. Mater. 2017, 743, 417-421. [CrossRef]

25. Krasnov, A.N.; Dorozhkina, L.A.; Trubkin, N.V.; Groznova, E.O.; Myznikov, I.K. Vanadium mineralization of Samolazovsky gold deposit, Central Aldan District. Izv. Vuzov. Geol. I Razved. 2004, 5, 70-72. (In Russian)

26. Leontiev, V.I.; Bushuev, Y.Y.; Chernigovtsev, K.A. Samolazovskoe gold deposit (Central Aldan ore region): Geological structure and features of deep horizons mineralization. Reg. Geol. Metallog. 2018, 75, 90-103. (In Russian)

27. Kondratieva, L.A.; Minakov, A.V.; Kravchenko, A.A. Gold-telluride mineralization of the Nimgerkan ore cluster (Aldan shield). In Proceedings of the VNPK; Publishing House of the NEFU: Yakutsk, Russia, 2020; pp. 224-229. (In Russian)

28. Glushkova, E.G.; Nikiforova, Z.S. Comparative analysis of the proximal wash off placer gold and gold from metasomatites of Tabornoe ore field (West part of Aldan shield). Proc. Russ. Mineral. Soc. 2014, CXLIII, 66-73. (In Russian)

29. Zubkov, Y.A.; Sagir, A.V.; Chvarova, N.V. "Uguysky” type of large-volume gold deposits formed in the linear weathering crust (South-Western Yakutia). Otechestvennaya Geol. 2020, 2, 32-45. (In Russian)

30. Terekhov, A.V.; Molchanov, A.V.; Shatov, V.V.; Khorokhorina, E.I.; Soloviev, O.L. Typomorphism of native gold from the Cenozoic deposits of the Gorely creek and its connection with primary sources within the Verkhneamginskiy ore-alluvial cluster (Southern Yakutia). Reg. Geol. Metallog. 2016, 65, 93-103. (In Russian)

31. Kazhenkina, A.G. Micromineral inclusions in native gold of the Tayakhtakh creek (Khatyrkhaysky ore-alluvial cluster). In Proceedings of the Congress of the Russian Mineralogical Society "200 years of RMO”, Saint-Petersburg, Russia, 9-12 October 2017; Volume 1, pp. 229-231. (In Russian).

32. Anisimova, G.S.; Kondratieva, L.A.; Sokolov, E.P.; Kardashevskaya, V.N. Gold mineralization of the Lebedinsky and Kuranakh types in the Verkhneamginsky district (South Yakutia). Otechestvennaya Geol. 2018, 5, 3-13. (In Russian)

33. Anisimova, G.S.; Kondratieva, L.A.; Kardashevskaia, V.N. Characteristics of Supergene Gold of Karst Cavities of the Khokhoy Gold Ore Field (Aldan Shield, East Russia). Minerals 2020, 10, 139. [CrossRef]

34. Prokopyev, I.R.; Doroshkevich, A.G.; Ponomarchuk, A.V.; Redina, A.A.; Yegitova, I.V.; Ponomarev, J.D.; Sergeev, S.A.; Kravchenko, A.A.; Ivanov, A.I.; Sokolov, E.P.; et al. U-Pb SIMS and Ar-Ar geochronology, petrography, mineralogy and gold mineralization of the late Mesozoic Amga alkaline rocks (Aldan shield, Russia). Ore Geol. Rev. 2019, 109, 520-534. [CrossRef]

35. Anisimova, G.S.; Sokolov, E.P. The Bodorono deposit-New gold ore object of the Southern Yakutia. Ores Met. 2014, 5, 49-57. (In Russian)

36. Anisimova, G.S.; Sokolov, E.P. Altan-Chaidakh—Promising object of the Southern Yakutia. Otechestvennaya Geol. 2015, 5, 3-10. (In Russian)

37. Anisimova, G.S.; Sokolov, E.P.; Kardashevskaya, V.N. Gold-rare-metal (Au-Mo-Te-Bi) mineralization of the Upper-Algominsky gold-bearing region (Southern Yakutia). Otechestvennaya Geol. 2017, 5, 12-22. (In Russian)

38. Kardashevskaia, V.N.; Anisimova, G.S. Tellurides Pd, Ni, Bi, Pb and Ag from quartz veins of Dyvok ore occurrence (South Yakutia). In Proceedings of the VNPK; Publishing House of the NEFU: Yakutsk, Russia, 2019; pp. 32-35. (In Russian)

39. MAIK. Tectonics, Geodynamics and Metallogeny of the Territory of the Republic of Sakha (Yakutia); MAIK(International Academic Publishing Company) "Nauka/Interperiodics": Moscow, Russia, 2001; 571p. (In Russian) 
40. Anisimova, G.S.; Kondratieva, L.A.; Kardashevskaya, V.N. Weissbergite (TlSbS2) and avicennite (T12O3)—Rare thallium minerals. The first finds in Yakutia. Proc. Russ. Mineral. Soc. 2021, 2, 18-27. (In Russian)

41. Petrovskaya, N.V.; Fastalovich, A.I.; Ivanov, A.A. Materials on Gold Mineralogy; General Directorate for the Production of Special Non-Ferrous Metals: Moscow, Russia, 1952; 347p. (In Russian)

42. Nikolaeva, L.A.; Gavrilov, A.M.; Nekrasova, A.N.; Yablokova, S.V.; Shatilova, L.V. Native Gold of Ore and Placer Deposits of Russia; TSNIGRI: Moscow, Russia, 2015; 200p. (In Russian)

43. Groves, D.I.; Goldfarb, R.J.; Gebre-Mariam, M.; Hagemann, S.G.; Robert, F. Orogenic gold deposits: A proposed classification in the context of their crustal distribution and relationship to other gold deposit types. Ore Geol. Rev. 1998, 13, 7-27. [CrossRef]

44. Kovalenker, V.A. Ore-forming systems of epithermal gold and silver deposits: Concepts, reality, models. Probl. Ore Geol. Petrol. Mineral. Geochem. 2004, 39, 160-184. (In Russian)

45. Pals, D.W.; Spry, P.G.; Chryssoulis, S. Invisible gold and tellurium in arsenic rich pyrite from the Emperor gold deposit, Fiji: Implications for gold distribution and deposition. Econ. Geol. 2003, 98, 479-493. [CrossRef]

46. Large, R.R.; Maslennikov, V.; Robert, F.; Danyushevsky, L.V.; Chang, Z. Multistage sedimentary and metamorphic origin of pyrite and gold in the giant Sukhoi Log deposit, Lena gold province, Russia. Econ. Geol. 2007, 102, 1233-1267. [CrossRef]

47. Large, R.R.; Maslennikov, V. Invisible Gold Paragenesis and Geochemistry in Pyrite from Orogenic and Sediment-Hosted Gold Deposits. Minerals 2020, 10, 339. [CrossRef]

48. Vikentyev, I.V. Invisible and microscopic gold in pyrite: Methods and new data for massive sulfide ores of the Urals. Geol. Ore Depos. 2015, 57, 237-265. [CrossRef]

49. Gao, F.; Du, Y.; Pang, Z.; Du, Y.; Xin, F.; Xie, J. LA-ICP-MS Trace-Element Analysis of Pyrite from the Huanxiangwa Gold Deposit, Xiong'ershan District, China: Implications for ore genesis. Minerals 2019, 9, 157. [CrossRef]

50. Zhao, J.; Pring, A. Mineral Transformations in Gold-(Silver) Tellurides in the Presence of Fluids: Nature and Experiment. Minerals 2019, 9, 167. [CrossRef]

51. Kovalenker, V.A.; Safonov, Y.G.; Naumov, V.B.; Rusinov, V.L. The Epithermal Gold-Telluride Kochbulak Deposit. Geol. Ore Depos. 1997, 39, 107-128.

52. Kovalenker, V.A.; Plotinskaya, O.Y.; Koneev, R.I. Mineralogy of epithermal gold-sulfide-telluride ores of the Kairagach deposit (Uzbekistan). New Data Miner. 2003, 38, 45-56. (In Russian)

53. Islamov, F.; Kremenetsky, A.; Minzer, E.; Koneev, R. The Kochbulak-Kairagach ore field. In Au, Ag, and Cu Deposits of Uzbekistan. Excursion Guidebook; GFZ: Potsdam, Germany, 1999; pp. 91-106.

54. Koneev, R.I. Nanomineralogy of Gold in Epithermal Ore Deposits of the Chatkalo-Kuramin Region; Delta: Saint Petersburg, Russia, 2006; 218p. (In Russian)

55. Koneev, R.I.; Khalmatov, R.A.; Mun, Y.S. Nanomineralogy and nanochemistry of ores from gold deposits of Uzbekistan. Geol. Ore Depos. 2010, 52, 755-766. [CrossRef]

56. Shackleton, J.M.; Spry, P.G.; Bateman, R. Telluride mineralogy of the Golden Mile deposit, Kalgoorlie, Western Australia. Can. Miner. 2003, 41, 1503-1524. [CrossRef]

57. Kelley, K.D.; Romberger, S.B.; Beaty, D.W.; Pontius, J.A.; Snee, L.W.; Stein, H.J.; Thompson, T.B. Geochemical and geochronological constraints on the genesis of Au-Te deposits at Cripple Creek, Colorado. Econ. Geol. 1998, 93, 981-1012. [CrossRef]

58. Ahmad, M.; Solomon, M.; Walshe, J.L. Mineralogical and geochemical studies of the Emperor gold telluride deposit, Fiji. Econ. Geol. 1987, 82, 234-270. [CrossRef]

59. Cook, N.J.; Ciobanu, C.L.; Capraru, N.; Damian, G.; Cristea, P. Mineral assemblages from the vein salband at Sacarimb, Golden Quadrilateral, Romania: II. Tellurides. Geochem. Miner. Petrol. 2005, 43, 56-63.

60. Plotinskaya, O.Y.; Novoselov, K.A.; Kovalenker, V.A.; Zeltmann, R. Variations of the Forms of Finding Commercial Components at the Bereznyakovskoye Field (Southern Urals). Materials of the Annual Meeting of the RMO. 2006. Available online: http: //www.minsoc.ru/2006-2-51-0 (accessed on 17 October 2006). (In Russian)

61. Zhai, D.; Liu, J. Gold-telluride-sulfide association in the Sandaowanzi epithermal Au-Ag-Te deposit, NE China: Implications for phase equilibrium and physicochemical conditions. Miner. Petrol. 2014, 108, 853-871. [CrossRef]

62. Zhao, J.; Brugger, J.; Xia, F.; Ngothai, Y.; Chen, G.; Pring, A. Dissolution-reprecipitation vs. solid-state diffusion: Mechanism of mineral transformations in sylvanite, $(\mathrm{AuAg})_{2} \mathrm{Te}_{4}$, under hydrothermal conditions. Am. Miner. 2013, 98, 19-32. [CrossRef]

63. Zhao, J.; Brugger, J.; Grundler, P.V.; Xia, F.; Chen, G.; Pring, A. Mechanism and kinetics of a mineral transformation under hydrothermal conditions: Calaverite to metallic gold. Am. Miner. 2009, 94, 1541-1555. [CrossRef]

64. Xu, W.; Zhao, J.; Brugger, J.; Chen, G.; Pring, A. Mechanism of mineral transformations in krennerite, $\mathrm{Au}_{3} \mathrm{AgTe}_{8}, \mathrm{under}$ hydrothermal conditions. Am. Miner. 2013, 98, 2086-2095. [CrossRef]

65. Palyanova, G.A. Gold and Silver Minerals in Sulfide Ore. Geol. Ore Deposits 2020, 62, 383-406. [CrossRef]

66. Nesterenko, G.V. Forecast of Gold Mineralization by Placers (on the Example of the Regions of Southern Siberia); Nauka: Novosibirsk, Russia, 1991; p. 191. (In Russian)

67. Murzin, V.V.; Malyugin, A.A. Gold Typomorphism of the Supergene Zone (on the Example of the Urals); Ural Scientific Center AS: Sverdlovsk, Russia, 1987; p. 96. (In Russian)

68. Gamyanin, G.N.; Nekrasov, I.Y.; Samusikov, V.P. Maldonite from the gold ore occurrences of the Eastern Yakutia. Mineral. J. 1986, 8, 65-71. (In Russian)

69. Nekrasov, I.Y. Geochemistry, Geology and Genesis of Gold Deposits; Nauka: Moscow, Russia, 1991; p. 302. (In Russian) 
70. Ciobanu, C.L.; Cook, N.J.; Pring, A. Bismuth tellurides as gold scavengers. In Mineral Deposit Research: Meeting the Global Challenge; Mao, J.W., Bierlein, F.P., Eds.; Springer: Berlin, Germany, 2005; pp. 1383-1386.

71. Tooth, B.; Brugger, J.; Ciobanu, C.L.; Liu, W. Modelling of gold-scavenging by bismuth melts coexisting with hydrothermal fluids. Geology 2008, 36, 815-818. [CrossRef]

72. Okrugin, V.M.; Andreeva, E.; Etschmann, B.; Pring, A.; Li, K.; Zhao, J.; Griffiths, G.; Lumpkin, G.R.; Triani, G.; Brugger, J. Microporous gold: Comparison of textures from Nature and experiments. Am. Miner. 2014, 99, 1171-1174. [CrossRef]

73. Tolstykh, N.D.; Palyanova, G.A.; Bobrova, O.V.; Sidorov, E.G. Mustard Gold of the Gaching Ore Deposit (Maletoyvayam Ore Field, Kamchatka, Russia). Minerals 2019, 9, 489. [CrossRef] 